\title{
Review Article \\ Honey: A Potential Therapeutic Agent for Managing Diabetic Wounds
}

\author{
Fahmida Alam, ${ }^{1}$ Md. Asiful Islam, ${ }^{1}$ Siew Hua Gan, ${ }^{1}$ and Md. Ibrahim Khalil ${ }^{2}$ \\ ${ }^{1}$ Human Genome Centre, School of Medical Sciences, Universiti Sains Malaysia, 16150 Kubang Kerian, Kelantan, Malaysia \\ ${ }^{2}$ Department of Biochemistry and Molecular Biology, Jahangirnagar University, Savar, Dhaka-1342, Bangladesh
}

Correspondence should be addressed to Md. Ibrahim Khalil; drmikhalil@yahoo.com

Received 16 July 2014; Accepted 29 September 2014; Published 15 October 2014

Academic Editor: Pradeep Visen

Copyright (C) 2014 Fahmida Alam et al. This is an open access article distributed under the Creative Commons Attribution License, which permits unrestricted use, distribution, and reproduction in any medium, provided the original work is properly cited.

\begin{abstract}
Diabetic wounds are unlike typical wounds in that they are slower to heal, making treatment with conventional topical medications an uphill process. Among several different alternative therapies, honey is an effective choice because it provides comparatively rapid wound healing. Although honey has been used as an alternative medicine for wound healing since ancient times, the application of honey to diabetic wounds has only recently been revived. Because honey has some unique natural features as a wound healer, it works even more effectively on diabetic wounds than on normal wounds. In addition, honey is known as an "all in one" remedy for diabetic wound healing because it can combat many microorganisms that are involved in the wound process and because it possesses antioxidant activity and controls inflammation. In this review, the potential role of honey's antibacterial activity on diabetic woundrelated microorganisms and honey's clinical effectiveness in treating diabetic wounds based on the most recent studies is described. Additionally, ways in which honey can be used as a safer, faster, and effective healing agent for diabetic wounds in comparison with other synthetic medications in terms of microbial resistance and treatment costs are also described to support its traditional claims.
\end{abstract}

\section{Introduction}

Diabetes mellitus (DM) is a progressive and chronic endocrine disorder that primarily results in hyperglycemia (excess glucose in the blood). Globally, diabetes is considered to be one of the major health problems with increasing prevalence. The prevalence of diabetes among all age groups worldwide was $2.8 \%$ in 2000 (171 million) and is estimated to increase (4.4\%) by 2030 (366 million). At present, 200 million people worldwide are suffering from diabetes and this figure is predicted to increase up to 333 million by the end of 2025 . The highest (relative and absolute) increment will occur in developing countries, where the prevalence will rise from $4.2 \%$ to $5.6 \%[1,2]$.

Data from large epidemiological studies have indicated that the worldwide incidence of type I DM has been increasing by $2-5 \%$ with an approximate prevalence of one in 300 by 18 years of age in the United States [3]. The global prevalence of type $2 \mathrm{DM}$ (T2DM) has shown rapid growth over the past few decades. According to the U.S. National Health and Nutrition Examination Survey, more than $40 \%$ of U.S. adults have diabetes or are prediabetic, which has doubled (from $4 \%$ to $8 \%$ ) in the past 40 years $[4,5]$. By the year 2025 , it is estimated that there will be 40 million diabetic patients in China and India alone [6]. According to the statistics of the International Diabetes Federation (IDF), two individuals will develop diabetes and another two will die of diabetes-related conditions every $10 \mathrm{sec}$ around the world [7]. Therefore, diabetes has become a very serious public health problem that causes a socioeconomic burden in many countries.

Diabetic patients tend to suffer from lower extremity complications including peripheral neuropathy, arterial disease, vascular problems, and ulcerations that contribute to the occurrence of diabetic foot infections. Approximately 25\% of diabetic patients have a higher reported lifetime risk of developing foot complications [8], and foot ulceration is the most common with an estimated annual incidence from 25 to $80 \%$ [9]. Most foot ulceration ultimately turns into diabetic gangrene especially if left untreated, contributing to approximately $80 \%$ of lower limb amputations [10-16]. More than $50 \%$ of diabetic wounds can exponentially increase the risk of below-knee amputation [17-19], which significantly enhances 
mortality in addition to contributing to a poor quality of life with enormous social, psychological, and economic consequences $[13,20-23]$. The majority of diabetic foot ulcerations involve the toes [24]. If proper treatment is not provided in due time, the amputation of the affected bone becomes unavoidable [25].

Wound healing is an intricate process involving skin (or another organ tissue) repair following injury [26]. In addition to being complex, it is also a dynamic process in which devitalized and missing cellular structures and tissue layers must be replaced. Despite recent advances in antimicrobial therapy, diabetic foot wounds remain a serious problem. Treating foot ulcers is protracted, intensive, and associated with high costs. For these reasons, various treatment approaches have been adopted including the use of topical wound-care therapies [27].

Although numerous topical and systemic agents have been used either solely or in combination to eradicate infections, many have been eliminated because of resistance. These agents have led to the emergence and subsequent rapid overgrowth of resistant bacterial strains, drug side effects, and organ-specific toxicity [28-30]. Diabetic wound infections caused by drug-resistant organisms are now becoming more common and have increasing resistance to commonly used antibiotics, ultimately leading to increased costs, morbidity, and mortality [31, 32]. With an increasing frequency of antibiotic-resistant pathogens, modern medicine directs attention to natural products with antimicrobial activity for clinical practice [27].

Honey is a collection of nectar from many plants, and this nectar is processed by honey bees. This natural product is well known for its high nutritional and prophylactic medicinal value [33]. Honey has potent antibacterial activity and is effective in preventing and clearing wound infections $[23,34]$. It has been used as a wound care product, and its use as a wound healing agent was reported for treating venous leg ulcers [35, 36], burns [37, 38], chronic leg ulcers [39], pressure ulcers [40,41], and exit sites for central venous catheters [42].

Honey has several natural substances that contribute to its antimicrobial activity including an osmotic effect, a naturally low $\mathrm{pH}$, and the production of hydrogen peroxide [4345]. Recent investigations have revealed that honey combats antibiotic-resistant strains of bacteria and prevents bacterial growth even when wounds are heavily infected [46, 47]. Furthermore, because honey is a natural product, it does not induce microbial resistance, even if the honey is unsuccessful in killing the microbes [48].

The objective of this review is to illustrate how and why honey should be considered as one of the best complementary and alternative medicines in diabetic wound management. It also provides scientific evidence to support the traditional use of honey in treating diabetic wounds.

\section{Honey in Association with Diabetic Wounds}

Although DM is almost harmless if controlled, the state of abnormally high blood glucose levels associated with the disease can lead to some serious complications. Although diabetic wounds are similar to wounds in normal patients, the healing process is different from that of other wounds. The most crucial part of diabetic wounds is that the healing process is notoriously slow. Hypoxia occurs in diabetic wounds, and it is caused by early inflammatory responses and a high load of reactive oxygen species (ROS) [49] induced by hyperglycemia in diabetic patients [50]. The formation of advanced glycation end-products (AGEs) under hyperglycemic conditions and interactions with their receptors (RAGE) are also associated with impaired wound healing among diabetic patients [51]. Several dysregulated cellular functions involved in diabetic wounds (defective T-cell immunity, defects in leukocyte chemotaxis, phagocytosis, bactericidal capacity, dysfunctions in fibroblasts and epidermal cells) were attributed to inadequate bacterial clearance and delayed or impaired repair in individuals with diabetes [52].

In addition, slow wound recovery generally increases treatment costs. It has been reported that the total direct costs for healing infected diabetic foot ulcers that do not require amputation are approximately $\$ 17,500$, whereas the costs for lower-extremity amputations are between $\$ 30,000$ and $\$ 33,500$ depending on the level of amputation [53]. Because of these high costs, scientists have been searching for a cheaper, naturally sourced remedy for diabetic wounds that is efficacious. Honey is a potential candidate because it is easily available and natural.

\section{The Effects of Honey Antioxidants on Diabetic Wounds}

Hydroxyl radicals and hypochlorite anions are formed from superoxide anions produced by activated polymorph nuclear neutrophils (PMNs) at the wound site, and they are considered to be important factors in impaired wound healing. The superoxide anion may also react with the nitric oxide that is produced by macrophages to form peroxynitrite, a third strong oxidant that damages the surrounding tissues $[54,55]$. Over many years, honeys from different parts of the world have been shown to be one of the highest potential natural products in which phenolics, flavonoids, ascorbic acids, and some enzymes (glucose oxidase and catalase) serve as potent antioxidants [56-59]. The antioxidants found in honey work on wounds through two means. First, the antioxidants fight against microorganisms and decrease infections at the site of the wound [60-62]. Second, the antioxidants reduce reactive oxygen species (ROS) and inflammations caused by the wound and aid in the healing process [62-65]. The combined antioxidant effects may have contributed to some successful clinical evidence from diabetic wounds showing more effective wound recoveries upon topical honey applications (Table 1).

\section{Antimicrobial Activity}

The broad spectrum antimicrobial activity of honey has been demonstrated in various studies. Honey reportedly exerts both bacteriostatic and bactericidal activities [66, 67]. 


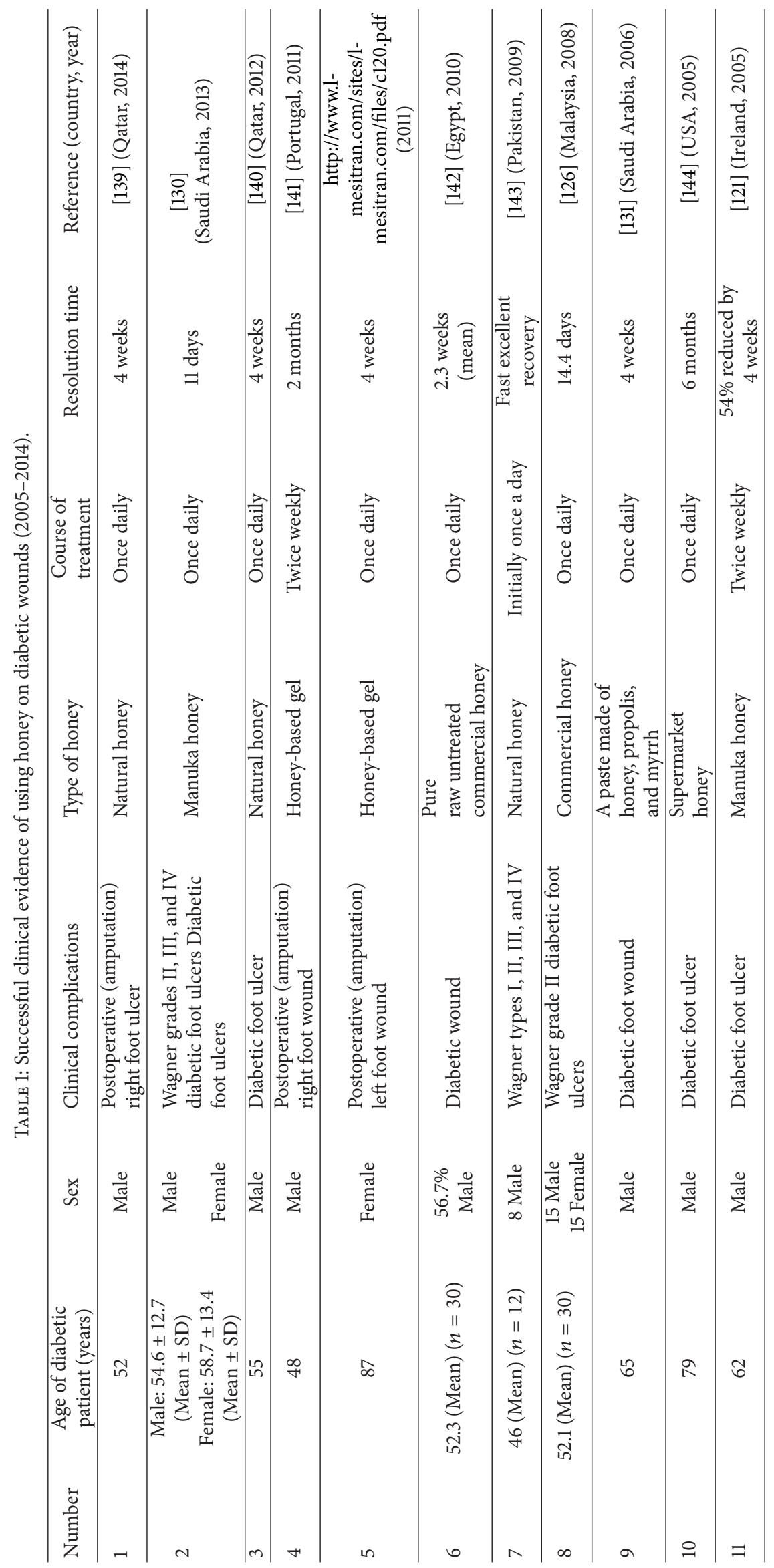


Because of the emergence of antibiotic-resistant microorganisms in diabetic wound treatment, the use of honey as an effective wound treatment is increasing because it can markedly inhibit the activities of wound-isolated microorganisms (Table 2). Some of the properties of honey (acidity, osmosis, hydrogen peroxide, and nitric oxide) that contribute to its antimicrobial activities against diabetic wounds are discussed below.

4.1. Honey Acidity. Honey is characteristically found at an acidic pH ranging between 3.2 and 4.5 [68]. The acidity of honey is primarily caused by the presence of gluconolactone or gluconic acid, and approximately $0.23-0.98 \%$ (1.8$7.5 \mathrm{mmol} / \mathrm{kg}$ ) [69] is formed through the action of a glucose oxidase enzyme produced by the bees. According to Al-Waili and Saloom [70], honey acidity is considered to be one of the factors that contributes to its antimicrobial activity. The glucose content of honey and its acidic $\mathrm{pH}$ may aid in bacterial killing by macrophages [71]. In addition, because of its acidic nature, honey can prevent microbial biofilm formation and cross contamination [72]. The acidity of honey creates an environment that facilitates the release of oxygen from the hemoglobin that is required for newly growing cells and the stimulation of white blood cells [73]. It is possible to increase the oxygen release rate from hemoglobin by lowering the wound $\mathrm{pH}$ via honey application, thus increasing tissue granulation [74] and improving the wound healing rate in diabetic patients [75]. Moreover, acidifying a wound through honey application can potentially reduce the protease activity [75] and provide a suitable environment for increasing fibroblast activity $[67,75]$, consequently promoting wound healing.

A previous study investigated the effects of Manuka honey dressing following two weeks of application on a nonhealing ulcer by collecting measurements of the change in wound surface $\mathrm{pH}$ and the ulcer size. A statistically significant reduction in the wound $\mathrm{pH}$ and size was observed. When the wound was in an environment with a $\mathrm{pH} \geq 8.0$, the size did not decrease. However, the $\mathrm{pH}$ was remarkably reduced to $\leq 7.6$ with a $30 \%$ decrease in the wound size upon honey application [76], indicating that the acidic condition created by honey favors wound healing.

4.2. Honey's Osmotic Effects. Honey that contains $<20 \%$ water is hyperosmolar [77]. By being hyperosmolar, honey creates an unfavorable environment for the growth and survival of microorganisms [78]. High osmolarity substrates such as honey, glucose, and sugar pastes can inhibit microbial growth because water molecules are chemically tied to the sugar molecules, thus creating a nonconducive environment for organism survival, leading to death [46]. Therefore, the hyperosmolar condition created by honey is also important for treating infections because it prevents the growth of bacteria and encourages rapid wound healing [79]. Sugar has been shown to accelerate wound healing in many patients with wounds, burns, and ulcers [80].

The sugar content of honey is purportedly responsible for its antibacterial activity, which is contributed entirely by the osmotic effect [81-84]. Hyperosmolar substances tend to draw fluid into the wound area to make a viscous solution, thus providing a protective layer against cross contamination [67]. Therefore, a highly osmolar solution, that is, honey, can be safely employed for diabetic wound treatments. However, only undiluted honey is sufficient for preventing microbial growth because its osmotic inhibition is lost when honey becomes diluted by wound exudates [66]. In addition, the osmotic action on bacteria is limited to the wound surface only, whereas other antibacterial factors can diffuse into wound tissues. However, the potency of the additional antibacterial factors varies as much as one hundredfold from honey to honey [85].

4.3. Hydrogen Peroxide. The hydrogen peroxide $\left(\mathrm{H}_{2} \mathrm{O}_{2}\right)$ that is found in honey is steadily produced by oxidation from the glucose oxidase enzyme (which is secreted into nectar from the hypopharyngeal gland of bees), and it is also a potent antibacterial agent [43]. Glucose oxidase is inactive in concentrated honey solutions (because of the low $\mathrm{pH}$ ), but upon honey dilution, it is activated and produces $\mathrm{H}_{2} \mathrm{O}_{2}[86,87]$. The production rate of $\mathrm{H}_{2} \mathrm{O}_{2}$ by glucose oxidase varies notably in honey and increases disproportionally depending on the degree of honey dilution [88]. Even when honey is applied to the wound area, the rate of $\mathrm{H}_{2} \mathrm{O}_{2}$ production, destruction, and dilution by exudates in a wound varies over time [89]. The $\mathrm{H}_{2} \mathrm{O}_{2}$ produced by honey is not cytotoxic because its $\mathrm{H}_{2} \mathrm{O}_{2}$ concentration is approximately 1000 times lower than that of the $3 \%$ solution commonly used as an antiseptic [90]. The low concentration of hydrogen peroxide may act as a "messenger" in healing promotion and may stimulate both fibroblasts and epithelial cells [67]. $\mathrm{H}_{2} \mathrm{O}_{2}$ reportedly stimulates fibroblast proliferation in vitro and angiogenesis in vivo [91]. Interestingly, the presence of high antioxidant levels in honey could reportedly confer protection to wound tissues from oxygen radicals that may be produced by $\mathrm{H}_{2} \mathrm{O}_{2}$ [92].

An experimental study using zebra fish has revealed a novel mechanism of early leukocyte migration to wounds as a result of the concentration gradient created by $\mathrm{H}_{2} \mathrm{O}_{2}$ [93]. Neutrophils release bactericidal reactive oxygen species and $\mathrm{H}_{2} \mathrm{O}_{2}$ kills bacteria and prevents infection. Macrophages arrive at the wound in response to environmental stimuli and release vascular endothelial growth factor (VEGF), an angiogenic factor that is crucial in the wound healing process. The released $\mathrm{H}_{2} \mathrm{O}_{2}$ increases macrophage VEGF through the oxidant induction of the VEGF promoter. This oxidant stimulation can be mediated by activated neutrophils [94]. Although only low levels of $\mathrm{H}_{2} \mathrm{O}_{2}$ accumulate in diluted honey, this is still an effective antimicrobial system because of its continuous production.

$\mathrm{H}_{2} \mathrm{O}_{2}$ has also been found to be more effective when supplied by continuous generation from glucose oxidase as opposed to when it is added as a bolus [95]. A substantial correlation has been found between the level of endogenous $\mathrm{H}_{2} \mathrm{O}_{2}$ and the extent of bacterial growth inhibition by honey [87]. In Canada, it was even suggested that the antimicrobial activity in some honeys depends on the endogenous $\mathrm{H}_{2} \mathrm{O}_{2}$ content. Based on a broth microdilution assay, the 
TABLE 2: The effectiveness of honey against microorganisms that are usually found in diabetic wounds.

Microorganisms found in diabetic wounds and references
Microorganisms found to have sensitivity to honey

Gram-positive aerobes

Staphylococcus aureus

Staphylococcus species [14, 145-153], including methicillin-resistant Staphylococcus aureus (MRSA), coagulase-negative Staphylococcus epidermidis

$\beta$-Hemolytic streptococci $[145,146,148,151,152]$, including Streptococcus pyogenes, Streptococcus pneumoniae

Bacillus species [145]

Corynebacterium sp. [14]

Proteus species $[14,146,147,149,150,153,162]$

Klebsiella species $[146,162]$

Pseudomonas aeruginosa $[14,148-150,153,162]$

Clostridium species $[146,147]$

Peptostreptococcus species [146, 148]

Enterococci $[14,147,148]$

Prevotella species [148]

Porphyromonas species [148]

Candida tropicalis $[149,150]$

Candida albicans [150]

Porphyromonas gingivalis
Honey origin and type with reference

Nigeria, unprocessed raw honey [154]

New Zealand, Pasture and Manuka honey [60]

United Arab Emirates, Manuka honey [155]

Saudi Arabia, commercial honey [156]

USA, commercial honey [157]

Rio San Pedro Ltd. Chile, Ulmo 90 honey [158]

Australia, Medihoney [159]

Nigeria, unprocessed raw honey [154]

United Arab Emirates, Manuka honey [155]

India, raw local honey [160]

Egypt, various monofloral honeys [161]
Escherichia coli

Proteus mirabilis (indole positive)

Klebsiella pneumoniae

Pseudomonas aeruginosa

\section{Gram-negative aerobes}

Nigeria, unprocessed raw honey [154]

United Arab Emirates, Manuka honey [155]

India, raw and processed local honey [160]

Rio San Pedro Ltd. Chile, Ulmo 90 honey [158]

Australia, Medihoney [159]

Saudi Arabia, commercial honey [156]

Nigeria, unprocessed raw honey [154]

Nigeria, unprocessed raw honey [154]

Australia, Medihoney [159]

Turkey; Anzer, Bayburt and Chest nut honey [163]

Ethiopia, Raw honey [164]

India, raw and processed local honey [160]

Rio San Pedro Ltd. Chile, Ulmo 90 honey [158]

India, local marketed honey [165]

Australia, Medihoney [159]

Saudi Arabia, commercial honey [156]

\section{Anaerobes}

Bacteroides fragilis

Clostridium welchii,

Clostridium tetani

Peptostreptococcus

Enterococcus faecalis

Prevotella intermedia,

Prevotella nigrescens

\section{Fungus}

Candida tropicalis

Candida albicans
Nigeria, unprocessed raw honey [154]

Nigeria, unprocessed raw honey [154]

Thailand, commercial honey [108]

Nigeria, unprocessed raw honey [154]

Australia, Medihoney [159]

Brazil, propolis [166]

New Zealand, Manuka honey [167]

Iran, local honey [168]

Nigeria, unprocessed raw honey [154]

United Arab Emirates, Manuka honey [155]

Iran, local honey [168] 
antibacterial activities of 42 Canadian honeys against the two bacterial strains Escherichia coli (ATCC 14948) and Bacillus subtilis (ATCC 6633) were analyzed. The findings indicated that all honey samples exhibited antibacterial activity with higher selectivity against $E$. coli than B. subtilis. Furthermore, antibacterial activity was correlated with $\mathrm{H}_{2} \mathrm{O}_{2}$ production in honey [96]. According to Brudzynski et al. [97], endogenous $\mathrm{H}_{2} \mathrm{O}_{2}$ inhibits $E$. coli in a concentration-dependent manner, although its minimum inhibitory concentration $\left(\mathrm{MIC}_{90}\right)$ value was twofold higher (at $2.5 \mathrm{mM}$ ) than those of exogenous $\mathrm{H}_{2} \mathrm{O}_{2}(1.25 \mathrm{mM})$. Therefore, the $\mathrm{H}_{2} \mathrm{O}_{2}$ that was liberated from honey could both control wound infection and improve wound healing.

4.4. Nitric Oxide. Nitric oxide (NO) plays an important role in the immunological response, inflammatory response, cell movement, and killing mechanisms of bacteria and viruses and also supports different types of organ-related functions. $\mathrm{NO}$ is very active in the proliferative stages during wound healing in patients $[98,99]$. Nitric oxide is able to reverse healing impairment in diabetic patients [100]. NO end products are known to be present in honey, and the concentration of these metabolites varies depending on the honey type [101]. This variation most likely contributed to the fact that honey antimicrobial activity also varies depending on the honey type or origin [102]. Moreover, these end products are increased by honey in various biological fluids such as urine, saliva, and blood plasma [103, 104].

The presence of NO metabolites in honey as well as the increased production of NO products by honey in different body fluids improves wound healing and provides the antimicrobial and immunoregulatory actions of NO [70, 101]. Furthermore, increased NO production from honey could explain the various effects of honey on immunity, bacterial infections, and wound healing $[101,103,104]$. Thus, the NO present in honey and NO-derived end products could be other potent ingredients that could help patients recover from diabetic wounds.

\section{Managing Wound Debridement}

Debridement is a very crucial process that facilitates the diabetic wound healing process. During debridement, old dead cells or tissues are removed by mechanical, chemical, surgical, or autolytic means. There are several mechanisms through which honey facilitates the rapid debridement of diabetic wounds and aids in healing. Honey contains protease enzyme that induces wound tissues to start autolytic debridement (self-digestion) [66]. Honey employs its intense osmolytic power to draw out lymph fluid from the wound tissue, thus creating the moist environment necessary for autolytically removing dead, damaged, or infected wound tissues. This mechanism ensures a continuous supply of proteases at the edge of the wound area and the overlying necrotic tissue. With this combined action, honey removes debris and effortlessly removes slough and necrotic tissue without any feeling of pain $[66,105]$.
The presence of $\mathrm{H}_{2} \mathrm{O}_{2}$ in honey also plays an important but indirect role by activating proteases during debridement. There are two processes through which protease can be activated during wound healing. First, $\mathrm{H}_{2} \mathrm{O}_{2}$ activates the inactive matrix metalloproteases in connective tissue into active protease [106]. Second, it blocks an inhibitor molecule that is present in diabetic wound tissue (which is responsible for inactivating neutrophil serine protease) and makes protease active [66]. Although wound healing impairment is reportedly related to high protease activity, the amount of protease activity in honey is highly regulated [107] because honey's anti-inflammatory properties can prevent excessive protease activity [66]. Because honey is a balanced natural resource for wound healing through proper debridement, it can be said to be a good natural diabetic wound healer.

\section{Controlling Wound Odor}

Honey has the potential ability to minimize offensivesmelling wounds through its strong osmotic action, which draws exudates and lymph fluid from the wound out towards the surface to add the moisture needed for autolytic debridement $[89,108]$. For example, a decrease in wound odor has been reported during the treatment of diabetic foot and leg ulcers [67]. Honey can exert its antimicrobial action both in vivo and in vitro against odor-producing bacteria, thus reducing their presence in wounds and consequently controlling malodor. Based on previous studies, honey can deodorize wound odor through two mechanisms. First, the presence of some anaerobic bacteria such as Bacteroides spp., Peptostreptococcus spp., and Prevotella spp. is documented to produce malodor. Second, wound odor is produced by the creation of amino acids through the decomposition of serum, tissue proteins, and dead cells by bacteria.

Honey acts by providing an abundance of glucose as a substrate in preference to amino acids for bacterial metabolism [41]. Therefore, glucose is converted to lactic acid by bacteria in the presence of honey instead of the malodorproducing ammonia, amines, and sulfur compounds typically produced by the metabolism of amino acids $[41,66,67$, 105]. Therefore, using honey on diabetic wounds can be very promising instead of using other synthetic products.

\section{Honey Minimizes Scar Formation}

The free radicals formed by excessive or prolonged inflammation can stimulate fibroblasts to produce a hypertrophic scar made of collagen fibers. Hypertrophic scars can be difficult to counteract during wound healing, and they can be alleviated by honey [66]. According to Vijaya and Nishteswar [73], honey stimulates epithelial cell growth at the skin level and produces soft, smooth, and regular scar surfaces in $80 \%$ of cases following complete healing. Topham (2002) reported [109] three potential mechanisms behind scarless healing when honey is applied to wounds as follows: (1) the production of hyaluronic acid from glucose suppresses the formation of fiber-forming collagens; (2) attaching sugar to collagen changes its structure and suppresses its activity; 
and (3) glucose creates an environment in the wound area that directs wound healing proteoglycans to act without producing excessive amounts of collagens.

\section{The Role of Nutrients in Honey}

The primary problem with diabetic wounds is poor or delayed healing. Healing problems are caused by the peripheral arterial diseases and peripheral neuropathy that can occur with diabetes, in which small blood vessels in different parts of the body, especially in the extremities (hands and feet), tend to be narrower, thus reducing the blood circulation to those areas. A lack of circulation in the extremities can result in a reduced supply of oxygen and nutrients to body tissue and nerves, and a normal supply is necessary for healing. Over time, the nerves in these areas may become damaged, decreasing the sensation of pain, temperature, and touch, making patients more vulnerable to injury.

Honey contains defined substances such as glucose, fructose, sucrose, minerals, vitamins, antioxidants, amino acids, and other products. The natural composition and actual proportion of each substance in honey may play a significant role in its mechanism of action and potency [75]. According to Molan [78], the presence of large quantities of assimilable sugars, vitamins, amino acids, and trace elements in honey contributes to its potential in stimulating tissue growth. A study by Viljanto and Raekallio [110] showed that there was an association between topical applications of nutrition to wounds and increased growth of granulation tissue. Molan [66] further noted that honey helps to stimulate angiogenesis and thereby increases oxygen and nutrients to the wound area for better wound healing. Nevertheless, more investigations are needed to identify the presence of other natural nutritional components in honey that may contribute to its wide biological and therapeutic effects on diabetic wounds.

\section{Inflammation Control}

Although inflammation is a vital part of normal responses to infection or injury from wounding, excessive or prolonged inflammation can obstruct diabetic wound healing or even cause further damage to the wound tissues [66]. Suppressing the inflammation and its associated pain in the wound area with honey reduces vasodilatation. This suppression results in reduced edema and exudates with positive effects on healing. The pressure created inside tissues from edema prevails through the blood flow of oxygen and nutrients through the capillaries [111], which are required for leukocytes to combat infections and fibroblast multiplication for connective tissue synthesis $[66,105]$. Thus, the anti-inflammatory effects of honey are crucial in treating diabetic wounds because they reduce edema and its associated pain and improve microcirculation with more oxygen and nutrients, leading to tissue repair [112].

According to Halliwell (1995), another consequence of excessive inflammation is ROS overproduction in tissues from phagocyte activity during the inflammatory process [113]. Being very reactive by nature, oxygen free radicals lead to tissue damage as a result of the breakdown of proteins, nucleic acids, and lipid components of cell membranes, and thus they prevent healing. The anti-inflammatory effects of honey can reduce ROS formation and prevent tissue destruction [114]. Although the mechanism behind honey's antiinflammatory activity is not well documented, a number of studies have supported its anti-inflammatory effects by showing that honey was able to control both acute and chronic inflammation [90]. Examples of honey's anti-inflammatory effects include (1) decreased amounts of inflammatory cells in histological studies of honey-treated biopsy specimens $[66,105]$ and (2) the ability of honey also to alter the activity of immunocompetent cells in the wound [67].

Honey also exerts significant actions on both innate and adaptive immune regulation. The stimulation of cytokine production (tumor necrosis factor alpha, interleukin- (IL-) $1 \beta$, and IL-6) by monocytes [115] and the induction of B and T lymphocyte proliferation [116] are directed by honey. A minimum concentration of honey is responsible for the active proliferation of peripheral blood $\mathrm{B}$ and $\mathrm{T}$ lymphocytes in addition to the activation of phagocytes in cell culture. The induction of proinflammatory cytokines by honey can also potentially activate immunological response to infections [115]. In addition, honey supplies glucose that is critical for the "respiratory burst" in macrophages that is needed to generate $\mathrm{H}_{2} \mathrm{O}_{2}$ and provides glycolysis substrates for energy production in macrophages [66]. Thus, honey acts as an effective agent to prevent diabetic wound inflammation and microbial infections.

\section{Benefits and Risks of Using Honey over Other Topical Wound Healing Agents}

Honey is not completely free from adverse effects. For example, there has been a report on "peppery" sensation when honey is applied to ulcers in a patient [39]. It is plausible that the low $\mathrm{pH}$ and high organic compounds in honey may contribute to the stinging sensation especially in some patients with more sensitized nerve endings. However, patients with neuropathic diabetic foot ulcers may be free from this experience due to lack of sensation. Besides the stinging sensation, honey also poses a small risk of wound infection as it may contain some clostridial spores. However, this risk can be reduced by using gamma-irradiated honey which can kill the spores while maintaining honey's antibacterial activity [78]. Nevertheless, to our knowledge, there has not been a single occurrence of wound infection contributed by clostridial spores with the topical application of honey in approximately 2000 cases reported so far. Although there may be some toxic effects from the ingestion of poorly handled honey [117], there have not been any documented toxic effects associated with the topical application of honey on diabetic wounds in comparison with the risk of using other conventional wound healing therapies (Table 3). Besides these few limitations, many studies reported honey as a nontoxic, nonallergenic, nonirritating healing agent with no cytotoxic effects [108, 118, 119]; it is a safe, cheap, and effective healing agent $[120,121]$. 
TABLE 3: Limitations of common topical agents used in wound healing.

\begin{tabular}{|c|c|c|}
\hline Name & Side effects and limitation & References \\
\hline \multirow{3}{*}{ Silver nitrate } & (1) Skin discoloration and irritation & {$[169]$} \\
\hline & (2) Toxicity to epithelium & {$[170]$} \\
\hline & $\begin{array}{l}\text { (3) The bacterial reduction of nitrate to nitrite may lead to methemoglobinemia with the use of } \\
\text { this topical agent }\end{array}$ & [171] \\
\hline Silver & Absorption, systemic distribution, and excretion in urine & [169] \\
\hline Polyhexamethylene biguanide & $\begin{array}{l}\text { Ineffective when there is a measurable degree of wound fluid suppuration because of its short } \\
\text { residence times on the wound site }\end{array}$ & [172] \\
\hline Proflavine & Induces mutations in bacterial and cell cultures & {$[173]$} \\
\hline \multirow{7}{*}{ Povidone iodine } & (1) Short residence times on the wound site & {$[172]$} \\
\hline & (2) Can cause severe metabolic acidosis & {$[174]$} \\
\hline & (3) Cytotoxicity against leukocytes, fibroblasts, and keratinocytes & {$[175]$} \\
\hline & (4) Polymorphonuclear leukocytes are inhibited by this topical agent & {$[176]$} \\
\hline & (5) Povidone iodine has also reportedly been inactivated by wound exudates & {$[177]$} \\
\hline & $\begin{array}{l}\text { (6) May "harden" wound eschar rather than softening it, thus increasing the difficulty and } \\
\text { discomfort of wound debridement }\end{array}$ & [178] \\
\hline & $\begin{array}{l}\text { (7) Should not be used during pregnancy, on a newborn, on small children, or on patients with } \\
\text { suspected or known thyroid disease }\end{array}$ & [179] \\
\hline \multirow{5}{*}{ Hydrogen peroxide } & (1) Formation of air emboli in wounds & {$[180]$} \\
\hline & $\begin{array}{l}\text { (2) The mechanical cleansing effect of hydrogen peroxide, often attributed to its "fizzing" (which } \\
\text { is caused by its decomposition into oxygen and water when it comes in contact with blood and } \\
\text { tissue fluids), is questionable }\end{array}$ & {$[181]$} \\
\hline & (3) Is toxic to fibroblasts & {$[182]$} \\
\hline & (4) Impairs the microcirculation of wounds & {$[183]$} \\
\hline & (5) Limited bactericidal effectiveness & [182] \\
\hline
\end{tabular}

Diluted iodine solutions

(iodine solution USP

[United States

Pharmacopeia] [2\% iodine,

$2.5 \%$ sodium iodide] and

May irritate tissue, stain the skin, and cause sensitization

Iodine tincture USP [ $2 \%$

iodine, $2.5 \%$ sodium iodide,

50\% alcohol])

\begin{tabular}{|c|c|c|}
\hline Povidone iodine & Contact dermatitis has been reported with prolonged uninjured skin exposure to ointment & [185] \\
\hline \multirow{2}{*}{ Chlorhexidine } & (1) Associated with few adverse effects on healing & {$[175]$} \\
\hline & (2) MRSA resistance has been found & [186] \\
\hline $\begin{array}{l}\text { Chlorhexidine gluconate } \\
\text { solution }\end{array}$ & Prolonged, repeated use may lead to contact dermatitis & [187] \\
\hline \multirow{4}{*}{ Acetic acid $0.5 \%$. } & (1) Acetic acid has demonstrated toxicity to fibroblasts in culture & {$[188]$} \\
\hline & (2) Reduced epithelial cell proliferation in culture & {$[189]$} \\
\hline & (3) Delayed healing of cultured epithelial autografts has been reported at $0.25 \%$ strength & {$[190]$} \\
\hline & (4) Acetic acid has been shown to reduce PMN function & {$[176]$} \\
\hline \multirow{4}{*}{$\begin{array}{l}\text { Sodium hypochlorite } \\
\text { (Dakin's solution) }\end{array}$} & (1) Has caused toxicity to fibroblasts in culture & {$[170]$} \\
\hline & (2) Toxicity to keratinocytes in culture & {$[170]$} \\
\hline & (3) Polymorphonuclear leukocyte viability is inhibited & {$[176]$} \\
\hline & $\begin{array}{l}\text { (4) Acidosis may result from continuous use over large-area wounds. This solution may also cause } \\
\text { pain }\end{array}$ & {$[178]$} \\
\hline
\end{tabular}


TABLE 3: Continued.

\begin{tabular}{|c|c|c|}
\hline Name & Side effects and limitation & References \\
\hline \multirow{5}{*}{ Silver sulfadiazine cream } & Topical pharmaceutical semisolid formulations (ointments and creams) & \\
\hline & $\begin{array}{l}\text { (1) Not effective for highly exuding wounds; rapidly absorbs fluid, loses its rheological } \\
\text { characteristics, and becomes mobile as it remains on wounds for longer periods of time }\end{array}$ & [172] \\
\hline & (2) 3-5\% incidence of reversible leucopenia & [191] \\
\hline & $\begin{array}{l}\text { (3) There is evidence that silver sulfadiazine is toxic to human keratinocytes and fibroblasts in } \\
\text { vitro }\end{array}$ & {$[170]$} \\
\hline & $\begin{array}{l}\text { (4) Should be avoided during pregnancy, on premature infants or on infants younger than } 2 \\
\text { months of age }\end{array}$ & [192] \\
\hline $\begin{array}{l}\text { Silver nitrate } \\
\text { ointment }\end{array}$ & Same problems as silver sulfadiazine cream & {$[172]$} \\
\hline Neosporin & Hypersensitivity is more common because of the presence of neomycin in the ointment & {$[178]$} \\
\hline \multirow{3}{*}{$\begin{array}{l}\text { Nitrofurazone } 0.2 \% \\
\text { compound }\end{array}$} & (1) Bacteria may develop mild resistance with prolonged use & [178] \\
\hline & (2) Detrimental effects on the growth and migration of keratinocytes in culture & {$[170]$} \\
\hline & (3) The development of the usual symptoms of contact dermatitis (rash, local edema, and pruritus) & [178] \\
\hline \multirow{3}{*}{ Gentamicin $0.1 \%$ cream } & (1) Can inhibit PMN activity & [176] \\
\hline & (2) Skin hypersensitivity has been reported & {$[178]$} \\
\hline & $\begin{array}{l}\text { (3) Ototoxicity and nephrotoxicity can occur, particularly when used in large volumes or for an } \\
\text { extended period of time }\end{array}$ & [193] \\
\hline \multirow{5}{*}{$\begin{array}{l}\text { Mafenide acetate } 0.5 \% \\
\text { cream (Sulfamylon) }\end{array}$} & (1) Inhibits human keratinocytes and fibroblasts in vitro & {$[170]$} \\
\hline & (2) Mafenide suppresses PMN and lymphocyte activity & {$[31,51]$} \\
\hline & $\begin{array}{l}\text { (3) The chance of a sulfa allergy is higher with mafenide acetate, and rashes may be seen in } \\
\text { approximately } 50 \% \text { of patients receiving mafenide treatment }\end{array}$ & {$[177]$} \\
\hline & (4) Toxicity may increase in correlation with the duration of treatment and size of the treated area & {$[194]$} \\
\hline & (5) Painful upon application & {$[195]$} \\
\hline \multirow[t]{2}{*}{ Neomycin ointment } & $\begin{array}{l}\text { (1) Hypersensitivity reactions, particularly skin rashes, also occur more frequently with neomycin } \\
\text { (occurring in } 5 \%-8 \% \text { of patients) }\end{array}$ & [196] \\
\hline & (2) Ototoxicity and nephrotoxicity have been reported for large wounds & [193] \\
\hline
\end{tabular}

\section{Clinical Evidence}

Honey has been used as an orthodox alternative medicine to treat wounds for millennia [122]. Records from ancient Greece, Egypt, the Ayurveda of India, Hippocrates, Aristotle, and the Qu'ran all refer to the healing effects of honey [123], and it has now been rediscovered through rational clinical evidence. Table 1 summarizes the most recent (10 years) evidence of successful honey treatments against diabetic wounds from different parts of the world.

There have been reports of some case studies and clinical and randomized controlled trials which provide considerable evidences indicating the effectiveness of honey in wound healing. A study was conducted to determine whether honey (L-Mesitran) and silver-impregnated dressings are cytotoxic to human skin keratinocytes and dermal fibroblasts in vitro. The honey-based product showed excellent cytocompatibility with tissue cell cultures when compared with the silver dressing [119].

Efem [118] conducted a clinical trial using honey dressings to treat patients $(n=59)$ having recalcitrant wounds and ulcers of various etiologies. From this number, even though
47 of the patients had previously been treated with conventional treatments by using commercial wound dressings or antibiotics (both systemic and topical), they showed no signs of healing. Following topical application of honey however, the majority (58 of the 59 patients involved) have shown remarkable improvement indicating the effectiveness of honey application for wound healing.

Dunford and Hanano [124] conducted a prospective, nonrandomized study to compare the effects of honey treatment on 40 patients with venous leg ulcers that failed to heal following 12 weeks of compression therapy. Significant reduction in ulcer pain and size with prompt deodorization were reported after honey treatment, further indicating its effectiveness.

In Greece, Manuka honey-impregnated dressings significantly reduced the healing time and provided rapid disinfection of neuropathic diabetic foot ulcers in type 2 diabetic patients when compared to conventional dressings [125]. In Turkey, a five-week randomized clinical trial was conducted to compare honey dressings $(n=15)$ versus an ethoxy-diaminoacridine plus nitrofurazone dressings $(n=11)$ on pressure ulcer healing. Patients who were treated by honey dressing 
had significantly better Pressure Ulcer Scale for Healing tool (PUSH tool) scores when compared to subjects treated with the ethoxy-diaminoacridine plus nitrofurazone dressing [41].

In Nigeria, 59 patients with wounds and ulcers, most of which had failed to heal with conventional treatment, were treated with unprocessed honey. The majority showed remarkable improvement following topical application of honey [118].

In Malaysia, the effects of honey dressing were compared with a controlled dressing group (povidone iodine followed by normal saline) for 30 Wagner's grade II diabetic foot ulcers in a prospective study. The authors concluded that honey dressing was a safe, alternative dressing for Wagner's grade II diabetic foot ulcers [126].

Some studies showed evidence that combination of honey with other compounds can be beneficial for wound healing. In Jordan, a study reported that the use of honey/normal saline dressing is more effective in reducing the healing time, cost of hospital stay, rate of amputation and irritation due to dressing material in diabetic foot ulcers as opposed to iodine/hydrogen peroxide dressing [127].

In a case series study, combined, noncontact, low-frequency ultrasound and topical application of medical honey effectively reduced wound dimensions, hastened wound closure, promoted cleansing of the wound bed, and stimulated wound healing in patients with chronic and delayed healing wounds of various etiologies and anatomical locations [128].

In Saudi Arabia, mixtures of Acacia honey, Commiphora molmol (Myrrh), and Nigella sativa (Black seed) showed effective antibacterial activities on clinical isolates from diabetic foot wounds [129]. However, they recommended that further research is needed to determine the most effective combination of these natural products in a clinical setting. In Saudi Arabia, a randomized controlled study revealed that a combination of conventional treatment for diabetic foot ulcers with Manuka honey-impregnated dressings is superior compared to using conventional treatment alone in controlling wound infection, in promoting complete healing process, and in decreasing the rate of minor amputations [130].

In Egypt, a deep wound with tissue loss in the right foot of a 65-year-old male patient with diabetes mellitus was successfully treated with a paste $(800 \mathrm{mg}$ bee propolis, $50 \mathrm{~g}$ myrrh, mixed together in honey) which healed following four weeks of usage [131].

\section{The Acceptance of Honey among Patients with Diabetic Wounds}

Honey has attracted attention from patients because of its cost effectiveness and as an alternative wound treatment option that has been applied since ancient times [132]. In rural communities, there was a positive response towards local honey as the treatment of choice among patients [133]. Because honey is sticky, diabetic patients may feel discomfort when applying honey to their foot ulcers. A review of 40 patients treated with antibacterial honey for venous ulcers revealed both positive outcomes and high patient acceptance [124]. Another review of 34 patients using honey for diabetic foot ulcers showed positive outcomes with encouraging patient acceptance [133]. Another study reported "patient comfort" levels as high for $88 \%$ with honey wound gel applications and $93 \%$ with honey alginate [134]. These studies showed no local or systemic atopic reactions to honey. Therefore, honey can be suggested for use as a safe and satisfying healing agent when applied topically to diabetic wounds.

\section{Guidelines for Honey Application on Wound}

Only good quality honey produced specifically for wound care and accepted by the regulatory authorities should be used. Some examples of medical grade honey with standardized antibacterial activity for use in wound management are Apiban (Apimed: Cambridge, New Zealand), Woundcare 18+ (Comvita: Te Puke, New Zealand), and Medihoney (Capilano: Richlands, Queensland, Australia) [66].

Heating of honey above $37^{\circ} \mathrm{C}$ should generally be avoided since its enzyme content is easily destroyed by exposure to both heat and light [78]. In addition, honey should be stored in a cool place (approximately $20^{\circ} \mathrm{C}$ ) and the storage containers should be made of either amber glass bottles or sachet of aluminum foils to protect honey from light. It is suggested to avoid storage of honey in plastic containers as plasticizers may leech from plastic and contaminate the honey [135].

The type of honey dressing product should be based on the wound type. The alginate honey dressing is especially attractive for being flexible, simple application, nonadherent to the wound surface and is less painful upon removal [136]. The frequency of dressing change is generally determined by the amount of exudates. However, no evidence is available to suggest the optimum frequency of dressing change needed.

To prevent contamination, the outer dressing must be changed whenever it is moist with exudate. When the amount of drainage decreases, the dressing can be left on for longer periods (4-7 days) which eventually reduces the frequency of dressing changes [136].

It has been reported that honey should be evenly applied on the dressing pad rather than directly onto the wound. Eddy et al. [77] suggested applying honey from 1 to 4 times daily. Nevertheless, the required dosage of honey on the wound depends on the amount of exudates present; the beneficial effects of honey will be reduced if honey is diluted by large amount of exudates. On the other hand, deep wounds require larger amounts of honey to exert antibacterial activity effectively. Therefore, dressings that hold sufficient honey in the wound area are useful to be therapeutically effective.

Honey should be immediately applied on the wound for better outcome as well as to reduce the risk of microbial contamination in honey. In addition, maximum coverage of inflamed wound areas by honey with highest contact is recommended. In case of using nonadherent dressing, it should be porous enough to allow the diffusion of honey components into the wound [137].

To debride hard eschar, dressings soaked in diluted honey (a mixture of 1 volume of honey with 3 volumes of saline) 
can be applied to allow better diffusion of honey until debridement is achieved [66].

\section{Future Directions}

Honey is (relatively) extensively used to treat diabetic wound patients; however, consistent and rapid healing has yet to be achieved. Some of the latest clinical evidence indicates that there is a wide healing duration range (from 11 days to 6 months) in diabetic wounds after using honey. To reduce this discrepancy, it is important to investigate the best honey composition that is most suitable for treating diabetic wounds even though there are already a few standardized honeys approved for wound care [138]. Therefore, more studies are needed to determine the characteristics present in honey to be termed "standard to treat against diabetic wounds." The factors that affect honey standardization include the honey source (monofloral and multifloral honey), honey type (processed or raw honey), honey origin (natural honey, commercial or those sold in the supermarkets), and the type and size of the diabetic wounds under treatment.

\section{Conclusions}

Honey is an alternative medicine that is considered to be a suitable therapy with improved outcomes. It is a cost-effective and safe natural agent with rapid diabetic wound healing capacity. However, additional successful clinical evidence is required with validated laboratory findings to establish honey as one of the most effective alternative topical medicines for treating diabetic wounds.

\section{Conflict of Interests}

The authors declare that there is no conflict of interests regarding the publication of this paper.

\section{References}

[1] M. Bahrami, A. Ataie-Jafari, S. Hosseini, M. H. Foruzanfar, M. Rahmani, and M. Pajouhi, "Effects of natural honey consumption in diabetic patients: an 8-week randomized clinical trial," International Journal of Food Sciences and Nutrition, vol. 60, no. 7, pp. 618-626, 2009.

[2] S. Wild, G. Roglic, A. Green, R. Sicree, and H. King, "Global prevalence of diabetes estimates for the year 2000 and projections for 2030," Diabetes Care, vol. 27, no. 5, pp. 1047-1053, 2004.

[3] D. M. Maahs, N. A. West, J. M. Lawrence, and E. J. MayerDavis, "Epidemiology of type 1 diabetes," Endocrinology and Metabolism Clinics of North America, vol. 39, no. 3, pp. 481-497, 2010.

[4] C. C. Cowie, K. F. Rust, E. S. Ford et al., "Full accounting of diabetes and pre-diabetes in the U.S. population in 1988-1994 and 2005-2006," Diabetes Care, vol. 32, no. 2, pp. 287-294, 2009.

[5] E. W. Gregg, B. L. Cadwell, Y. J. Cheng et al., "Trends in the prevalence and ratio of diagnosed to undiagnosed diabetes according to obesity levels in the U.S.," Diabetes Care, vol. 27, no. 12, pp. 2806-2812, 2004.
[6] K.-H. Yoon, J.-H. Lee, J.-W. Kim et al., "Epidemic obesity and type 2 diabetes in Asia," The Lancet, vol. 368, no. 9548, pp. 1681$1688,2006$.

[7] International Diabetes Federation, "World Diabetes Media Kit: every 10 seconds 1 person dies of diabetes," Brussels, Belgium, 2007, http://www.idf.org/webdata/docs/World_Diabetes_Day_ Media_Kit.pdf.

[8] N. Singh, D. G. Armstrong, and B. A. Lipsky, "Preventing foot ulcers in patients with diabetes," The Journal of the American Medical Association, vol. 293, no. 2, pp. 217-228, 2005.

[9] L. A. Lavery, K. R. Higgins, D. R. Lanctot et al., "Preventing diabetic foot ulcer recurrence in high-risk patients: use of temperature monitoring as a self-assessment tool," Diabetes Care, vol. 30, no. 1, pp. 14-20, 2007.

[10] R. E. Pecoraro, G. E. Reiber, and E. M. Burgess, "Pathways to diabetic limb amputation: basis for prevention," Diabetes Care, vol. 13 , no. 5 , pp. 513-521, 1990.

[11] J. Larsson, C.-D. Agardh, J. Apelqvist, and A. Stenström, "Long term prognosis after healed amputation in patients with diabetes," Clinical Orthopaedics and Related Research, no. 350, pp. 149-158, 1998.

[12] A. M. Aljadi and K. M. Yusoff, "Isolation and identification of phenolic acids in Malaysian honey with antibacterial properties," Turkish Journal of Medical Sciences, vol. 33, no. 4, pp. 229236, 2003.

[13] M. P. Khanolkar, S. C. Bain, and J. W. Stephens, "The diabetic foot," QJM, vol. 101, no. 9, pp. 685-695, 2008.

[14] R. G. Frykberg and A. Veves, "Diabetic foot infections," Diabetes/Metabolism Reviews, vol. 12, no. 3, pp. 255-270, 1996.

[15] J. A. Mayfield, G. E. Reiber, L. J. Sanders, D. Janisse, and L. M. Pogach, "Preventive foot care in people with diabetes," Diabetes Care, vol. 26, no. 1, pp. S78-S79, 2003.

[16] American Diabetes Association, "Consensus development conference on diabetic foot wound care: 7-8 April 1999, Boston, Massachusetts. American Diabetes Association," Diabetes Care, vol. 22, no. 8, pp. 1354-1360, 1999.

[17] D. G. Armstrong and B. A. Lipsky, "Diabetic foot infections: stepwise medical and surgical management," International Wound Journal, vol. 1, no. 2, pp. 123-132, 2004.

[18] L. A. Lavery, D. G. Armstrong, R. P. Wunderlich, M. J. Mohler, C. S. Wendel, and B. A. Lipsky, "Risk factors for foot infections in individuals with diabetes," Diabetes Care, vol. 29, no. 6, pp. 1288-1293, 2006.

[19] B. A. Lipsky, A. R. Berendt, H. G. Deery et al., "Diagnosis and treatment of diabetic foot infections," Clinical Infectious Diseases, vol. 39, no. 7, pp. 885-910, 2004.

[20] T. Zgonis, J. J. Stapleton, V. A. Girard-Powell, and R. T. Hagino, "Surgical management of diabetic foot infections and amputations," AORN journal, vol. 87, no. 5, pp. 935-950, 2008.

[21] N. Tentolouris, S. Al-Sabbagh, M. G. Walker, A. J. M. Boulton, and E. B. Jude, "Mortality in diabetic and nondiabetic patients after amputations performed from 1990 to 1995: a 5-year followup study," Diabetes Care, vol. 27, no. 7, pp. 1598-1604, 2004.

[22] C. J. Schofield, G. Libby, G. M. Brennan, R. R. Macalpine, A. D. Morris, and G. P. Leese, "Mortality and hospitalization in patients after amputation: a comparison between patients with and without diabetes," Diabetes Care, vol. 29, no. 10, pp. 22522256, 2006.

[23] D. Boutoille, A. Féraille, D. Maulaz, and M. Krempf, "Quality of life with diabetes-associated foot complications: comparison between lower-limb amputation and chronic foot ulceration," Foot and Ankle International, vol. 29, no. 11, pp. 1074-1078, 2008. 
[24] G. E. Reiber, B. A. Lipsky, and G. W. Gibbons, "The burden of diabetic foot ulcers," The American Journal of Surgery, vol. 176, no. 2, pp. 5-10, 1998.

[25] J. M. Robbins, G. Strauss, D. Aron, J. Long, J. Kuba, and Y. Kaplan, "Mortality rates and diabetic foot ulcers: is it time to communicate mortality risk to patients with diabetic foot ulceration?" Journal of the American Podiatric Medical Association, vol. 98, no. 6, pp. 489-493, 2008.

[26] D. Nguyen, D. Orgill, and G. Murphy, The Pathophysiologic Basis for Wound Healing and Cutaneous Regeneration, Elsevier, 2009.

[27] J. Majtan, "Methylglyoxal-a potential risk factor of manuka honey in healing of diabetic ulcers," Evidence-based Complementary and Alternative Medicine, vol. 2011, Article ID 295494 , 5 pages, 2011.

[28] S. M. Tambe, L. Sampath, and S. M. Modak, "In vitro evaluation of the risk of developing bacterial resistance to antiseptics and antibiotics used in medical devices," Journal of Antimicrobial Chemotherapy, vol. 47, no. 5, pp. 589-598, 2001.

[29] P. Appelgren, V. Björnhagen, K. Bragderyd, C. E. Jonsson, and U. Ransjö, "A prospective study of infections in burn patients," Burns, vol. 28, no. 1, pp. 39-46, 2002.

[30] A. Abd-El Aal, M. El-Hadidy, N. El-Mashad, and A. El-Sebaie, "Antimicrobial effect of bee honey in comparison to antibiotics on organisms isolated from infected burns," Annals of Burns and Fire Disasters, vol. 20, no. 2, pp. 83-88, 2007.

[31] R. Saraf, V. Bowry, D. Rao, P. Saraf, and P. Molan, "The antimicrobial efficacy of Fijian honeys against clinical isolates from diabetic foot ulcers," Journal of ApiProduct and ApiMedical Science, vol. 1, no. 3, pp. 64-71, 2009.

[32] D. J. Payne, M. N. Gwynn, D. J. Holmes, and D. L. Pompliano, "Drugs for bad bugs: confronting the challenges of antibacterial discovery," Nature Reviews Drug Discovery, vol. 6, no. 1, pp. 2940, 2007.

[33] N. H. A. El-sound, "Honey between traditional uses and recent medicine," Macedonian Journal of Medical Sciences, vol. 5, no. 2, pp. 205-214, 2012.

[34] J. Stephen-Haynes, E. Gibson, and M. Greenwood, "Chitosan: a natural solution for wound healing," Journal of Community Nursing, vol. 28, no. 1, pp. 48-53, 2014.

[35] G. Gethin and S. Cowman, "Manuka honey vs. hydrogela prospective, open label, multicentre, randomised controlled trial to compare desloughing efficacy and healing outcomes in venous ulcers," Journal of Clinical Nursing, vol. 18, no. 3, pp. 466474, 2009.

[36] A. Jull, N. Walker, V. Parag, P. Molan, and A. Rodgers, "Randomized clinical trial of honey-impregnated dressings for venous leg ulcers," British Journal of Surgery, vol. 95, no. 2, pp. 175-182, 2008.

[37] C. Sheckter, M. M. van Vliet, N. M. Krishnan, and W. L. Garner, "Cost-effectiveness comparison between topical silver sulfadiazine and enclosed silver dressing for partial-thickness burn treatment," Journal of Burn Care and Research, vol. 35, no. 4, pp. 284-290, 2014.

[38] B. K. H. L. Boekema, L. Pool, and M. M. W. Ulrich, "The effect of a honey based gel and silver sulphadiazine on bacterial infections of in vitro burn wounds," Burns, vol. 39, no. 4, pp. 754-759, 2013.

[39] O. M. Oluwatosin, J. K. Olabanji, O. A. Oluwatosin, L. A. Tijani, and H. U. Onyechi, "A comparison of topical honey and phenytoin in the treatment of chronic leg ulcers," African Journal of Medicine and Medical Sciences, vol. 29, no. 1, pp. 31-34, 2000.
[40] B. Biglari, P. H. Vd Linden, A. Simon, S. Aytac, H. J. Gerner, and A. Moghaddam, "Use of Medihoney as a non-surgical therapy for chronic pressure ulcers in patients with spinal cord injury," Spinal Cord, vol. 50, no. 2, pp. 165-169, 2012.

[41] Ü. Y. Güneş and I. Eşer, "Effectiveness of a honey dressing for healing pressure ulcers," Journal of Wound, Ostomy and Continence Nursing, vol. 34, no. 2, pp. 184-190, 2007.

[42] D. W. Johnson, C. Van Eps, D. W. Mudge et al., "Randomized, controlled trial of topical exit-site application of honey (Medihoney) versus mupirocin for the prevention of catheterassociated infections in hemodialysis patients," Journal of the American Society of Nephrology, vol. 16, no. 5, pp. 1456-1462, 2005.

[43] L. M. Bang, C. Buntting, and P. Molan, "The effect of dilution on the rate of hydrogen peroxide production in honey and its implications for wound healing," Journal of Alternative and Complementary Medicine, vol. 9, no. 2, pp. 267-273, 2003.

[44] M. Subrahmanyam, A. Sahapure, N. Nagane, V. Bhagwat, and J. Ganu, "Effects of topical application of honey on burn wound healing," Annals of Burns and fire Disasters, vol. 14, pp. 143-145, 2001.

[45] R. White and P. Molan, A Summary of Published Clinical Research on Honey in Wound Management, Wounds, Aberdeen, UK, 2005.

[46] P. C. Molan, "The evidence supporting the use of honey as a wound dressing," The International Journal of Lower Extremity Wounds, vol. 5, no. 1, pp. 40-54, 2006.

[47] A. K. J. Ahmed, M. J. Hoekstra, J. J. Hage, and R. B. Karim, "Honey-medicated dressing: transformation of an ancient remedy into modern therapy," Annals of Plastic Surgery, vol. 50, no. 2, pp. 143-148, 2003.

[48] Y. Maeda, A. Loughrey, J. A. P. Earle et al., "Antibacterial activity of honey against community-associated methicillin-resistant Staphylococcus aureus (CA-MRSA)," Complementary Therapies in Clinical Practice, vol. 14, no. 2, pp. 77-82, 2008.

[49] A. A. Tandara and T. A. Mustoe, "Oxygen in wound healingmore than a nutrient," World Journal of Surgery, vol. 28, no. 3, pp. 294-300, 2004.

[50] F. Giacco and M. Brownlee, "Oxidative stress and diabetic complications," Circulation Research, vol. 107, no. 9, pp. 10581070, 2010.

[51] M. S. P. Huijberts, N. C. Schaper, and C. G. Schalkwijk, "Advanced glycation end products and diabetic foot disease," Diabetes/Metabolism Research and Reviews, vol. 24, no. 1, pp. S19-S24, 2008.

[52] R. G. Sibbald and K. Y. Woo, "The biology of chronic foot ulcers in persons with diabetes," Diabetes/Metabolism Research and Reviews, vol. 24, supplement 1, pp. S25-S30, 2008.

[53] G. R. Tennvall and J. Apelqvist, "Health-economic consequences of diabetic foot lesions," Clinical Infectious Diseases, vol. 39, supplement 2, pp. S132-S139, 2004.

[54] J. Kanta, "The role of hydrogen peroxide and other reactive oxygen species in wound healing," Acta Medica, vol. 54, no. 3, pp. 97-101, 2011.

[55] U. auf dem Keller, A. Kümin, S. Braun, and S. Werner, "Reactive oxygen species and their detoxification in healing skin wounds," Journal of Investigative Dermatology Symposium Proceedings, vol. 11, no. 1, pp. 106-111, 2006.

[56] A. Islam, I. Khalil, N. Islam et al., "Physicochemical and antioxidant properties of Bangladeshi honeys stored for more than one year," BMC Complementary and Alternative Medicine, vol. 12, article 177, 2012. 
[57] M. I. Khalil, M. Moniruzzaman, L. Boukraâ et al., "Physicochemical and antioxidant properties of algerian honey," Molecules, vol. 17, no. 9, pp. 11199-11215, 2012.

[58] M. Al-Mamary, A. Al-Meeri, and M. Al-Habori, "Antioxidant activities and total phenolics of different types of honey," Nutrition Research, vol. 22, no. 9, pp. 1041-1047, 2002.

[59] M. I. Khalil, N. Alam, M. Moniruzzaman, S. A. Sulaiman, and S. H. Gan, "Phenolic acid composition and antioxidant properties of malaysian honeys," Journal of Food Science, vol. 76, no. 6, pp. C921-C928, 2011.

[60] R. A. Cooper, P. C. Molan, and K. G. Harding, "Antibacterial activity of honey against strains of Staphylococcus aureus from infected wounds," Journal of the Royal Society of Medicine, vol. 92, no. 6, pp. 283-285, 1999.

[61] N. S. Al-Waili, "Investigating the antimicrobial activity of natural honey and its effects on the pathogenic bacterial infections of surgical wounds and conjunctiva," Journal of Medicinal Food, vol. 7, no. 2, pp. 210-222, 2004.

[62] L. Estevinho, A. P. Pereira, L. Moreira, L. G. Dias, and E. Pereira, "Antioxidant and antimicrobial effects of phenolic compounds extracts of Northeast Portugal honey," Food and Chemical Toxicology, vol. 46, no. 12, pp. 3774-3779, 2008.

[63] K. A. Mathews and A. G. Binnington, "Wound management using honey," Compendium on Continuing Education for the Practicing Veterinarian, vol. 24, no. 1, pp. 53-59, 2002.

[64] V. Bansal, B. Medhi, and P. Pandhi, "Honey—a remedy rediscovered and its therapeutic utility," Kathmandu University Medical Journal, vol. 3, no. 3, pp. 305-309, 2005.

[65] T.-T. Phan, L. Wang, P. See, R. J. Grayer, S.-Y. Chan, and S. T. Lee, "Phenolic compounds of Chromolaena adorata protect cultured skin cells from oxidative damage: implication for cutaneous wound healing," Biological and Pharmaceutical Bulletin, vol. 24, no. 12, pp. 1373-1379, 2001.

[66] P. C. Molan, "Re-introducing honey in the management of wounds and ulcers-theory and practice," Ostomy/Wound management, vol. 48, no. 11, pp. 28-40, 2002.

[67] P. E. Lusby, A. Coombes, and J. M. Wilkinson, "Honey: a potent agent for wound healing?" Journal of Wound Ostomy \& Continence Nursing, vol. 29, no. 6, pp. 295-300, 2002.

[68] E. Crane, Honey. A Comprehensive Survey, Russak, Crane, Tex, USA, 1975.

[69] J. W. White Jr., Physical Characteristics of Honey, 1975.

[70] N. S. Al-Waili and K. Y. Saloom, "Effects of topical honey on post-operative wound infections due to gram positive and gram negative bacteria following caesarean sections and hysterectomies," European Journal of Medical Research, vol. 4, no. 3, pp. 126-130, 1999.

[71] G. B. Ryan and G. Majno, "Acute inflammation. A review," The American Journal of Pathology, vol. 86, no. 1, pp. 183-276, 1977.

[72] K. F. Cutting, "Honey and contemporary wound care: an overview," Ostomy Wound Management, vol. 53, no. 11, pp. 4954, 2007.

[73] K. K. Vijaya and K. Nishteswar, "Wound healing activity of honey: a pilot study," $A Y U$, vol. 33, no. 3, pp. 374-377, 2012.

[74] P. B. Olaitan, O. E. Adeleke, and I. O. Ola, "Honey: a reservoir for microorganisms and an inhibitory agent for microbes," African Health Sciences, vol. 7, no. 3, pp. 159-165, 2007.

[75] N. S. Al-Waili, K. Salom, and A. A. Al-Ghamdi, "Honey for wound healing, ulcers, and burns; data supporting its use in clinical practice," TheScientificWorldJournal, vol. 11, pp. 766-787, 2011.
[76] G. Ndayisaba, L. Bazira, E. Habonimana, and D. Muteganya, "Clinical and bacteriological outcome of wounds treated with honey. An analysis of a series of 40 cases," Revue de Chirurgie Orthopedique et Reparatrice de l'Appareil Moteur, vol. 79, no. 2, pp. 111-113, 1993.

[77] J. J. Eddy, M. D. Gideonsen, and G. P. Mack, "Practical considerations of using topical honey for neuropathic diabetic foot ulcers: a review," Wisconsin Medical Journal, vol. 107, no. 4, pp. 187-190, 2008.

[78] P. C. Molan, "The role of honey in the management of wounds." Journal of wound care, vol. 8, no. 8, pp. 415-418, 1999.

[79] H. G. Archer, S. Barnett, S. Irving, K. R. Middleton, and D. V. Seal, "A controlled model of moist wound healing: comparison between semi-permeable film, antiseptics and sugar paste," Journal of Experimental Pathology, vol. 71, no. 2, pp. 155-170, 1990.

[80] R. A. Knutson, L. A. Merbitz, M. A. Creekmore, and H. G. Snipes, "Use of sugar and povidone-iodine to enhance wound healing: five years' experience," Southern Medical Journal, vol. 74, no. 11, pp. 1329-1335, 1981.

[81] S. D. Somerfield, "Honey and healing," Journal of the Royal Society of Medicine, vol. 84, no. 3, p. 179, 1991.

[82] A. Green, "Wound healing properties of honey," British Journal of Surgery, vol. 75, no. 12, p. 1278, 1988.

[83] R. E. Condon, "Curious interaction of bugs and bees," Surgery, vol. 113, no. 2, pp. 234-235, 1993.

[84] F. I. Seymour and K. S. West, "Honey-its role in medicine," Medical Times, vol. 79, no. 2, pp. 104-108, 1951.

[85] P. C. Molan, "The antibacterial activity of honey: 2. Variation in the potency of the antibacterial activity," Bee World, vol. 73, no. 2, pp. 59-76, 1992.

[86] A. I. Schepartz and M. H. Subers, "The glucose oxidase of honey I. Purification and some general properties of the enzyme," BBA-Enzymological Subjects, vol. 85, no. 2, pp. 228-237, 1964.

[87] J. W. White Jr., M. H. Subers, and A. I. Schepartz, "The identification of inhibine, the antibacterial factor in honey, as hydrogen peroxide and its origin in a honey glucose-oxidase system," Biochimica et Biophysica Acta, vol. 73, no. 1, pp. 57-70, 1963.

[88] P. C. Molan, “The antibacterial activity of honey: 1 . The nature of the antibacterial activity," Bee World, vol. 73, no. 1, pp. 5-28, 1992.

[89] B. Pieper, "Honey-based dressings and wound care: an option for care in the United States," Journal of Wound, Ostomy and Continence Nursing, vol. 36, no. 1, pp. 60-66, 2009.

[90] C. Dunford, "The use of honey-derived dressings to promote effective wound management," Professional Nurse, vol. 20, no. 8, pp. 35-38, 2005.

[91] E. Tur, L. Bolton, and B. E. Constantine, "Topical hydrogen peroxide treatment of ischemic ulcers in the guinea pig: blood recruitment in multiple skin sites," Journal of the American Academy of Dermatology, vol. 33, no. 2, pp. 217-221, 1995.

[92] S. Frankel, G. E. Robinson, and M. R. Berenbaum, "Antioxidant capacity and correlated characteristics of 14 unifloral honeys," Journal of Apicultural Research, vol. 37, no. 1, pp. 27-31, 1998.

[93] S. K. Yoo and A. Huttenlocher, "Innate Immunity: Wounds Burst $\mathrm{H}_{2} \mathrm{O}_{2}$ Signals to Leukocytes," Current Biology, vol. 19, no. 14, pp. R553-R555, 2009.

[94] M. Cho, T. K. Hunt, and M. Z. Hussain, "Hydrogen peroxide stimulates macrophage vascular endothelial growth factor release," The American Journal of Physiology-Heart and Circulatory Physiology, vol. 280, no. 5, pp. H2357-H2363, 2001. 
[95] K. M. Pruitt and J. O. Tenovuo, The Lactoperoxidase System. Chemistry and Biological Significance, CRC Press, New York, NY, USA, 1985.

[96] K. Brudzynski, "Effect of hydrogen peroxide on antibacterial activities of Canadian honeys," Canadian Journal of Microbiology, vol. 52, no. 12, pp. 1228-1237, 2006.

[97] K. Brudzynski, K. Abubaker, L. St-Martin, and A. Castle, "Reexamining the role of hydrogen peroxide in bacteriostatic and bactericidal activities of honey," Frontiers in Microbiology, vol. 2, article 213, 2011.

[98] B. B. Childress and J. K. Stechmiller, "Role of nitric oxide in wound healing." Biological research for nursing, vol. 4, no. 1, pp. $5-15,2002$.

[99] S. Moncada, R. M. J. Palmer, and E. A. Higgs, "Nitric oxide: physiology, pathophysiology, and pharmacology," Pharmacological Reviews, vol. 43, no. 2, pp. 109-142, 1991.

[100] A. Schwentker, Y. Vodovotz, R. Weller, and T. R. Billiar, "Nitric oxide and wound repair: role of cytokines?" Nitric OxideBiology and Chemistry, vol. 7, no. 1, pp. 1-10, 2002.

[101] N. S. Al-Waili, "Identification of nitric oxide metabolites in various honeys: effects of intravenous honey on plasma and urinary nitric oxide metabolites concentrations," Journal of Medicinal Food, vol. 6, no. 4, pp. 359-364, 2003.

[102] O. A. Moore, L. A. Smith, F. Campbell, K. Seers, H. J. McQuay, and R. A. Moore, "Systematic review of the use of honey as a wound dressing," BMC Complementary and Alternative Medicine, vol. 1, pp. 2-10, 2001.

[103] N. Al-Waili and N. Saleeb, "Honey increased nitric oxide end product in saliva of healthy volunteer," in FASEB Conference, vol. 236, San Diego, Calif, USA, April 2003, Abstract 236.

[104] N. S. Al-Waili and N. S. Boni, "Honey increased saliva, plasma, and urine content of total nitrite concentrations in normal individuals," Journal of Medicinal Food, vol. 7, no. 3, pp. 377-380, 2004.

[105] R. White, "The benefits of honey in wound management," Nursing Standard, vol. 20, no. 10, pp. 57-66, 2005.

[106] G. J. Peppin and S. J. Weiss, "Activation of the endogenous metalloproteinase, gelatinase, by triggered human neutrophils," Proceedings of the National Academy of Sciences of the United States of America, vol. 83, no. 12, pp. 4322-4326, 1986.

[107] G. S. Ashcroft, K. Lei, W. Jin et al., "Secretory leukocyte protease inhibitor mediates non-redundant functions necessary for normal wound healing," Nature Medicine, vol. 6, no. 10, pp. 1147$1153,2000$.

[108] W. Phuapradit and N. Saropala, "Topical application of honey in treatment of abdominal wound disruption," Australian and New Zealand Journal of Obstetrics and Gynaecology, vol. 32, no. 4, pp. 381-384, 1992.

[109] J. Topham, "Why do some cavity wounds treated with honey or sugar paste heal without scarring?" Journal of wound care, vol. 11, no. 2, pp. 53-55, 2002.

[110] J. Viljanto and J. Raekallio, "Local hyperalimentation of open wounds," British Journal of Surgery, vol. 63, no. 6, pp. 427-430, 1976.

[111] A. Chant, "The biomechanics of leg ulceration," Annals of the Royal College of Surgeons of England, vol. 81, no. 2, pp. 80-85, 1999.

[112] B. Pieper, "Honey-based dressings and wound care," Journal of Wound, Ostomy and Continence Nursing, vol. 36, no. 6, article 589, 2009.
[113] B. Halliwell, "Oxygen radicals, nitric oxide and human inflammatory joint disease," Annals of the Rheumatic Diseases, vol. 54, no. 6, pp. 505-510, 1995.

[114] L. Flohé, R. Beckmann, H. Giertz, and G. Loschen, OxygenCentred Free Radicals as Mediators of Inflammation, Academic Press, London, UK, 1985.

[115] A. J. Tonks, R. A. Cooper, K. P. Jones, S. Blair, J. Parton, and A. Tonks, "Honey stimulates inflammatory cytokine production from monocytes," Cytokine, vol. 21, no. 5, pp. 242-247, 2003.

[116] M. Takeuchi, M. Fukuda, K. Kobayashi et al., "Jungle honey enhances immune function and antitumor activity," EvidenceBased Complementary and Alternative Medicine, vol. 2011, Article ID 908743, 8 pages, 2011.

[117] M. N. Islam, M. I. Khalil, M. A. Islam, and S. H. Gan, "Toxic compounds in honey," Journal of Applied Toxicology, vol. 34, no. 7, pp. 733-742, 2014.

[118] S. Efem, "Clinical observations on the wound healing properties of honey," British Journal of Surgery, vol. 75, no. 7, pp. 679-681, 1988.

[119] D. F. du Toit and B. J. Page, "An in vitro evaluation of the cell toxicity of honey and silver dressings," Journal of wound care, vol. 18, no. 9, pp. 383-389, 2009.

[120] A. B. Jull, A. Rodgers, and N. Walker, "Honey as a topical treatment for wounds," Cochrane Database of Systematic Reviews, no. 4, Article ID CD005083, 2008.

[121] G. Gethin and S. Cowman, "Case series of use of Manuka honey in leg ulceration," International Wound Journal, vol. 2, no. 1, pp. 10-15, 2005.

[122] G. Majno, The Healing Hand: Man and Wound in the Ancient World, Harvard University Press, 1991.

[123] J. A. Stewart, O. L. McGrane, and I. S. Wedmore, "Wound care in the wilderness: is there evidence for honey?" Wilderness and Environmental Medicine, vol. 25, no. 1, pp. 103-110, 2014.

[124] C. E. Dunford and R. Hanano, "Acceptability to patients of a honey dressing for non-healing venous leg ulcers," Journal of Wound Care, vol. 13, no. 5, pp. 193-197, 2004.

[125] A. V. Kamaratos, K. N. Tzirogiannis, S. A. Iraklianou, G. I. Panoutsopoulos, I. E. Kanellos, and A. I. Melidonis, "Manuka honey-impregnated dressings in the treatment of neuropathic diabetic foot ulcers," International Wound Journal, vol. 11, no. 3 , pp. 259-263, 2014.

[126] A. Shukrimi, A. R. Sulaiman, A. Y. Halim, and A. Azril, "A comparative study between honey and povidone iodine as dressing solution for Wagner type II diabetic foot ulcers," Medical Journal of Malaysia, vol. 63, no. 1, pp. 44-46, 2008.

[127] S. K. Hammouri, "The role of honey in the management of diabetic foot ulcers," Journal of Research in Medical Sciences, vol. 11, no. 2, pp. 20-22, 2004.

[128] I. Chernev, P. A. Liguori, S. L. Senno, K. L. Peters, and J. M. Bowers, "Combined noncontact, lowo-frequency ultrasound and medical honey for the treatment of chronic wounds: a case series," Journal of Wound, Ostomy and Continence Nursing, vol. 37, no. 4, pp. 421-425, 2010.

[129] H. A. Alzahrani, B. A. Bakhotmah, and L. Boukraâ, "In Vitro susceptibility of diabetic wound bacteria to mixtures of honey, Commiphora molmol and Nigella sativa," Open Nutraceuticals Journal, vol. 4, pp. 172-175, 2011.

[130] M. Al Saeed, "Therapeutic efficacy of conventional treatment combined with Manuka honey in the treatment of patients with diabetic foot ulcers: a randomized controlled study," Egyptian Journal of Hospital Medicine, vol. 53, pp. 1064-1071, 2013. 
[131] M. Lotfy, G. Badra, W. Burham, and F. Q. Alenzi, "Combined use of honey, bee propolis and myrrh in healing a deep, infected wound in a patient with diabetes mellitus," British Journal of Biomedical Science, vol. 63, no. 4, pp. 171-173, 2006.

[132] G. Majno, The Healing Hand: Man and Wound in the Ancient World, Harvard University Press, Cambridge, Mass, USA, 1975.

[133] S. A. Nawfar, C. S. Han, M. Paiman, and M. Iskandar, "A randomized control trial comparing the effects of manuka honey and tualang honey on wound granulation of post debridement diabetic foot wounds," Journal of ApiProduct \& ApiMedical Science, vol. 3, no. 1, pp. 18-25, 2011.

[134] A. Freeman, K. May, and P. Wraight, "Honey: the bees' knees for diabetic foot ulcers?” Wound Practice \& Research, vol. 18, no. 3, p. 144, 2010.

[135] M. S. Nurul Syazana, S. H. Gan, A. S. Halim, N. S. M. Shah, and H. A. Sukari, "Analysis of volatile compounds of Malaysian Tualang (Koompassia excelsa) honey using gas chromatography mass spectrometry," African Journal of Traditional, Complementary and Alternative Medicines, vol. 10, no. 2, pp. 180-188, 2013.

[136] E. A. van der Weyden, "The use of honey for the treatment of two patients with pressure ulcers," British Journal of Community Nursing, vol. 8, no. 12, pp. S14-S20, 2003.

[137] P. C. Molan, "Potential of honey in the treatment of wounds and burns," The American Journal of Clinical Dermatology, vol. 2, no. 1, pp. 13-19, 2001.

[138] P. C. Molan and J. A. Betts, "Clinical usage of honey as a wound dressing: an update," Journal of Wound Care, vol. 13, no. 9, pp. 353-356, 2004.

[139] H. Mohamed, M. A. Salma, B. Al Lenjawi et al., "Enhancing primary healing post ray amputation in a diabetic patient: efficacy of natural honey," Journal of Diabetic Foot Complications, vol. 6, no. 1, pp. 13-18, 2014.

[140] H. Mohamed, M. Abu Salma, B. Allenjawi et al., "Natural honey as an adjunctive alternative in the management of diabetic foot ulcers," Wound Practice \& Research, vol. 20, no. 4, p. 212, 2012.

[141] N. Candeias and M. Cardoso, "Management of diabetic foot ulceration with honey," Wounds UK, vol. 7, no. 3, pp. 84-86, 2011.

[142] A. M. Moghazy, M. E. Shams, O. A. Adly et al., "The clinical and cost effectiveness of bee honey dressing in the treatment of diabetic foot ulcers," Diabetes Research and Clinical Practice, vol. 89, no. 3, pp. 276-281, 2010.

[143] A. Makhdoom, M. S. Khan, M. A. Lagahari, M. Q. Rahopoto, S. M. Tahir, and K. A. Siddiqui, "Management of diabetic foot by natural honey," Journal of Ayub Medical College, Abbottabad, vol. 21, no. 1, pp. 103-105, 2009.

[144] J. J. Eddy and M. D. Gideonsen, "Topical honey for diabetic foot ulcers," The Journal of Family Practice, vol. 54, no. 6, pp. 533-535, 2005.

[145] L. Xu, S. V. McLennan, L. Lo et al., "Bacterial load predicts healing rate in neuropathic diabetic foot ulcers," Diabetes Care, vol. 30, no. 2, pp. 378-380, 2007.

[146] M. S. Bader, "Diabetic foot infection," The American Family Physician, vol. 78, no. 1, pp. 71-82, 2008.

[147] T. J. Louie, J. G. Bartlett, F. P. Tally, and S. L. Gorbach, "Aerobic and anaerobic bacteria in diabetic foot ulcers," Annals of Internal Medicine, vol. 85, no. 4, pp. 461-463, 1976.

[148] P. G. Bowler, B. I. Duerden, and D. G. Armstrong, "Wound microbiology and associated approaches to wound management," Clinical Microbiology Reviews, vol. 14, no. 2, pp. 244-269, 2001.
[149] E. Bansal, A. Garg, S. Bhatia, A. Attri, and J. Chander, "Spectrum of microbial flora in diabetic foot ulcers," Indian Journal of Pathology and Microbiology, vol. 51, no. 2, pp. 204-208, 2008.

[150] D. A. Chincholikar and R. B. Pal, "Study of fungal and bacterial infections of the diabetic foot," Indian Journal of Pathology and Microbiology, vol. 45, no. 1, pp. 15-22, 2002.

[151] G. M. Caputo, P. R. Cavanagh, J. S. Ulbrecht, G. W. Gibbons, and A. W. Karchmer, "Assessment and management of foot disease in patients with diabetes," The New England Journal of Medicine, vol. 331, no. 13, pp. 854-860, 1994.

[152] B. A. Lipsky, R. E. Pecoraro, S. A. Larson, M. E. Hanley, and J. H. Ahroni, "Outpatient management of uncomplicated lowerextremity infections in diabetic patients," Archives of Internal Medicine, vol. 150, no. 4, pp. 790-797, 1990.

[153] A. T. El-Tahawy, "Bacteriology of diabetic foot infections," Saudi Medical Journal, vol. 21, no. 4, pp. 344-347, 2000.

[154] S. E. E. Efem, K. T. Udoh, and C. I. Iwara, "The antimicrobial spectrum of honey and its clinical significance," Infection, vol. 20, no. 4, pp. 227-229, 1992.

[155] N. S. Al-Waili, M. Akmal, F. S. Al-Waili, K. Y. Saloom, and A. Ali, "The antimicrobial potential of honey from United Arab Emirates on some microbial isolates," Medical Science Monitor, vol. 11, no. 12, pp. BR433-BR438, 2005.

[156] B. Nzeako and J. Hamdi, "Antimicrobial potential of honey on some microbial isolates," Medical Sciences, vol. 2, no. 2, pp. 75$79,2000$.

[157] P. J. Taormina, B. A. Niemira, and L. R. Beuchat, "Inhibitory activity of honey against foodborne pathogens as influenced by the presence of hydrogen peroxide and level of antioxidant power," International Journal of Food Microbiology, vol. 69, no. 3, pp. 217-225, 2001.

[158] O. Sherlock, A. Dolan, R. Athman et al., "Comparison of the antimicrobial activity of Ulmo honey from Chile and Manuka honey against methicillin-resistant Staphylococcus aureus, Escherichia coli and Pseudomonas aeruginosa," BMC Complementary and Alternative Medicine, vol. 10, article 47, 2010.

[159] N. M. George and K. F. Cutting, "Antibacterial honey (Medihoney): in-vitro activity against clinical isolates of MRSA, VRE, and other multiresistant gram-negative organisms including Pseudomonas aeruginosa," Wounds, vol. 19, no. 9, p. 231, 2007.

[160] A. Chauhan, V. Pandey, K. Chacko, and R. Khandal, "Antibacterial activity of raw and processed honey," Electronic Journal of Biology, vol. 6, no. 3, pp. 58-66, 2010.

[161] A. G. Hegazi, "Antimicrobial activity of different Egyptian honeys as comparison of Saudi Arabia honey," Research Journal of Microbiology, vol. 6, no. 5, pp. 488-495, 2011.

[162] A. Ramani, R. Ramani, R. Shivananda, P. G. Shivananda, and G. N. Kundaje, "Bacteriology of diabetic foot ulcers," Indian Journal of Pathology and Microbiology, vol. 34, no. 2, pp. 81-87, 1991.

[163] K. Sevgi, A. Rezzan, U. Esra, and K. Sengül, "Antioxidant and antimicrobial activities of selected Turkish honeys," Hacettepe Journal of Biology and Chemistry, vol. 36, no. 2, pp. 163-172, 2008.

[164] A. Mulu, B. Tessema, and F. Derbie, "In vitro assessment of the antimicrobial potential of honey on common human pathogens," Ethiopian Journal of Health Development, vol. 18, no. 2, pp. 107-111, 2004. 
[165] V. Mullai and T. Menon, "Bactericidal activity of different types of honey against clinical and environmental isolates of Pseudomonas aeruginosa," Journal of Alternative and Complementary Medicine, vol. 13, no. 4, pp. 439-442, 2007.

[166] F. A. Santos, E. M. A. Bastos, P. H. Rodrigues et al., "Susceptibility of Prevotella intermedia/Prevotella nigrescens (and Porphyromonas gingivalis) to propolis (bee glue) and other antimicrobial agents," Anaerobe, vol. 8, no. 1, pp. 9-15, 2002.

[167] S. Eick, G. Schäfer, J. Kwieciński, J. Atrott, T. Henle, and W. Pfister, "Honey-a potential agent against Porphyromonas gingivalis: an in vitro study," BMC Oral Health, vol. 14, no. 1, article 24, 2014.

[168] A. R. Khosravi, H. Shokri, F. Katiraee, T. Ziglari, and M. Forsi, "Fungicidal potential of different Iranian honeys against some pathogenic Candida species," Journal of Apicultural Research, vol. 47, no. 4, pp. 256-260, 2008.

[169] A. B. Lansdown, "Silver. 2: toxicity in mammals and how its products aid wound repair," Journal of Wound Care, vol. 11, no. 5, pp. 173-177, 2002.

[170] E. C. Smoot III, J. O. Kucan, A. Roth, N. Mody, and N. Debs, "In vitro toxicity testing for antibacterials against human keratinocytes," Plastic and Reconstructive Surgery, vol. 87, no. 5, pp. 917-924, 1991.

[171] C. A. Moyer, D. L. Brentano, D. L. Gravens, H. W. Margraf, and W. W. Monafo Jr., "Treatment of large human burns with $0.5 \%$ silver nitrate solution," Archives of Surgery, vol. 90, no. 6, pp. 812-867, 1965.

[172] J. S. Boateng, K. H. Matthews, H. N. E. Stevens, and G. M. Eccleston, "Wound healing dressings and drug delivery systems: a review," Journal of Pharmaceutical Sciences, vol. 97, no. 8, pp. 2892-2923, 2008.

[173] Y. Iwamoto, L. R. Ferguson, A. Pearson, and B. C. Baguley, "Photo-enhancement of the mutagenicity of 9-anilinoacridine derivatives related to the antitumour agent amsacrine," Mutation Research: Fundamental and Molecular Mechanisms of Mutagenesis, vol. 268, no. 1, pp. 35-41, 1992.

[174] F. Dela Cruz, D. H. Brown, J. B. Leikin, C. Franklin, and D. O. Hryhorczuk, "Iodine absorption after topical administration," Western Journal of Medicine, vol. 146, no. 1, pp. 43-45, 1987.

[175] A. Drosou, A. Falabella, and R. S. Kirsner, "Antiseptics on wounds: an area of controversy," Wounds, vol. 15, no. 5, pp. 149166, 2003.

[176] J. F. Hansbrough, R. L. Zapata-Sirvent, and M. L. Cooper, "Effects of topical antimicrobial agents on the human neutrophil respiratory burst," Archives of Surgery, vol. 126, no. 5, pp. 603-608, 1991.

[177] W. W. Monafo and M. A. West, "Current treatment recommendations for topical burn therapy," Drugs, vol. 40, no. 3, pp. 364373, 1990.

[178] R. S. Ward and J. R. Saffle, “Topical agents in burn and wound care," Physical Therapy, vol. 75, no. 6, pp. 526-538, 1995.

[179] M. Steen, "Review of the use of povidone-iodine (PVP-I) in the treatment of burns," Postgraduate Medical Journal, vol. 69, no. 3, pp. S84-S92, 1993.

[180] J. W. Sleigh and S. P. K. Linter, "Hazards of hydrogen peroxide," The British Medical Journal, vol. 291, no. 6510, p. 1706, 1985.

[181] C. D. Brown and J. A. Zitelli, "A review of topical agents for wounds and methods of wounding: guidelines for wound management," Journal of Dermatologic Surgery and Oncology, vol. 19, no. 8, pp. 732-737, 1993.
[182] H. A. Shelanski and M. V. Shelanski, "PVP-iodine: history, toxicity and therapeutic uses," The Journal of the International College of Surgeons, vol. 25, no. 6, pp. 727-734, 1956.

[183] F. M. Tatnall, I. M. Leigh, and J. R. Gibson, "Comparative study of antiseptic toxicity on basal keratinocytes, transformed human keratinocytes and fibroblasts," Skin Pharmacology, vol. 3, no. 3, pp. 157-163, 1990.

[184] M. R. Jacobs and P. Zanowiak, Handbook of Nonprescriptive Drugs, American Pharmaceutical Association, Washington, D.C., USA, 9th edition, 1990.

[185] J. G. Marks Jr., "Allergic contact dermatitis to povidone-iodine," Journal of the American Academy of Dermatology, vol. 6, no. 4, pp. 473-475, 1982.

[186] B. D. Cookson, M. C. Bolton, and J. H. Platt, "Chlorhexidine resistance in methicillin-resistant Staphylococcus aureus or just an elevated MIC? An in vitro and in vivo assessment," Antimicrobial Agents and Chemotherapy, vol. 35, no. 10, pp. 1997-2002, 1991.

[187] Y. Greener, M. McCartney, and L. Jordan, "Assessment of the systemic effects, primary dermal irritation, and ocular irritation of chlorhexidine acetate solutions," Journal of the American College of Toxicology, vol. 4, no. 6, pp. 309-319, 1985.

[188] W. Lineaweaver, S. McMorris, D. Soucy, and R. Howard, "Cellular and bacterial toxicities of topical antimicrobials," Plastic and Reconstructive Surgery, vol. 75, no. 3, pp. 394-396, 1985.

[189] M. L. Cooper, S. T. Boyce, J. F. Hansbrough, T. J. Foreman, and D. H. Frank, "Cytotoxicity to cultured human keratinocytes of topical antimicrobial agents," Journal of Surgical Research, vol. 48, no. 3, pp. 190-195, 1990.

[190] G. G. Gallico, N. E. O’Connor, C. C. Compton, J. P. Remensnyder, O. Kehinde, and H. Green, "Cultured epithelial autografts for giant congenital nevi," Plastic and Reconstructive Surgery, vol. 84, no. 1, pp. 1-9, 1989.

[191] J. Hudspith and S. Rayatt, "ABC of burns: first aid and treatment of minor burns," The British Medical Journal, vol. 328, no. 7454, pp. 1487-1489, 2004.

[192] N. J. Montvale, Physicians' Desk Reference, Medical Economics Data Production Co, 49th edition, 1995.

[193] A. G. Gilman, L. S. Goodman, T. W. Rall, and F. Murad, The Pharmacological Basis of Therapeutics, Macmillan, New York, NY, USA, 1985.

[194] J. A. Moncrief, B. W. Haynes Jr., and C. L. Fox, “Topical therapy for control of bacteria in the burn wound," World Journal of Surgery, vol. 2, no. 2, pp. 151-165, 1978.

[195] H. N. Harrison, J. M. Shuck, and E. Caldwell, "Studies of the pain produced by mafenide acetate preparations in burns," Archives of Surgery, vol. 110, no. 12, pp. 1446-1449, 1975.

[196] M. T. Gette, J. G. Marks Jr., and M. E. Maloney, "Frequency of postoperative allergic contact dermatitis to topical antibiotics," Archives of Dermatology, vol. 128, no. 3, pp. 365-367, 1992. 


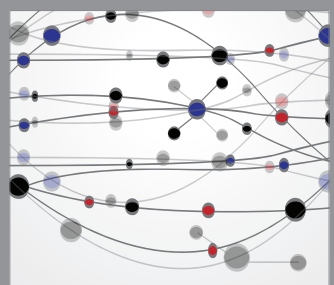

The Scientific World Journal
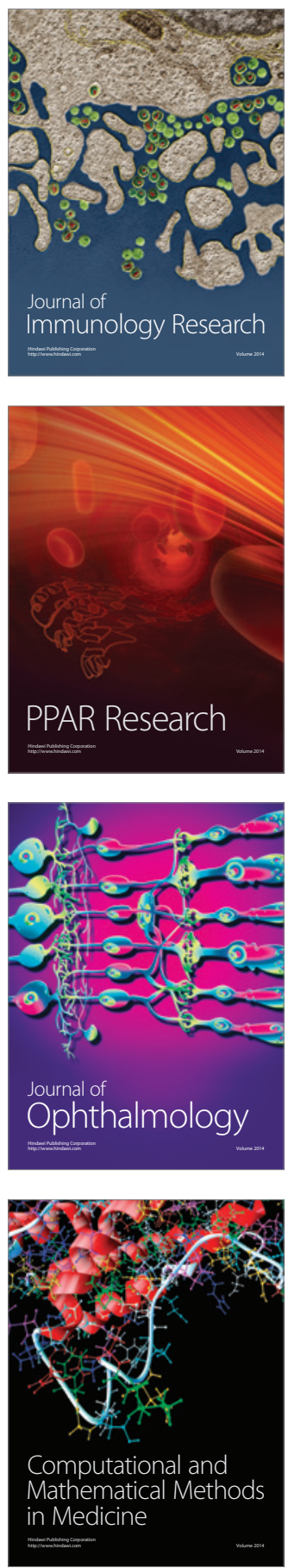

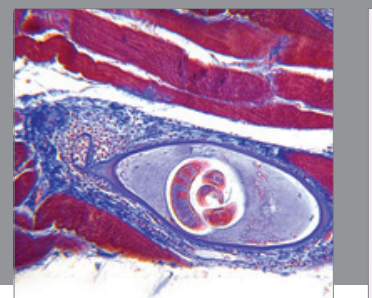

Gastroenterology

Research and Practice
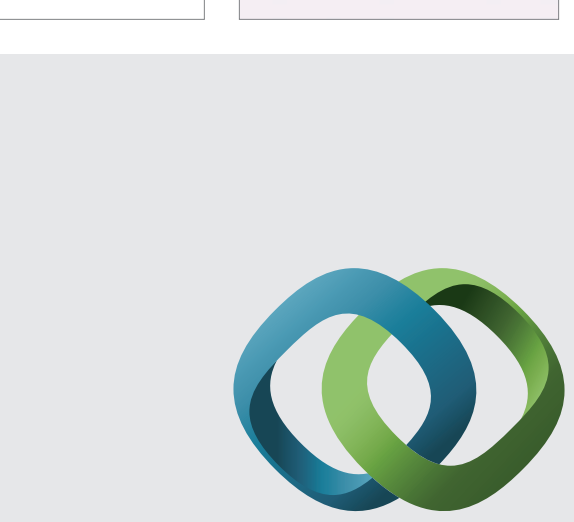

\section{Hindawi}

Submit your manuscripts at

http://www.hindawi.com
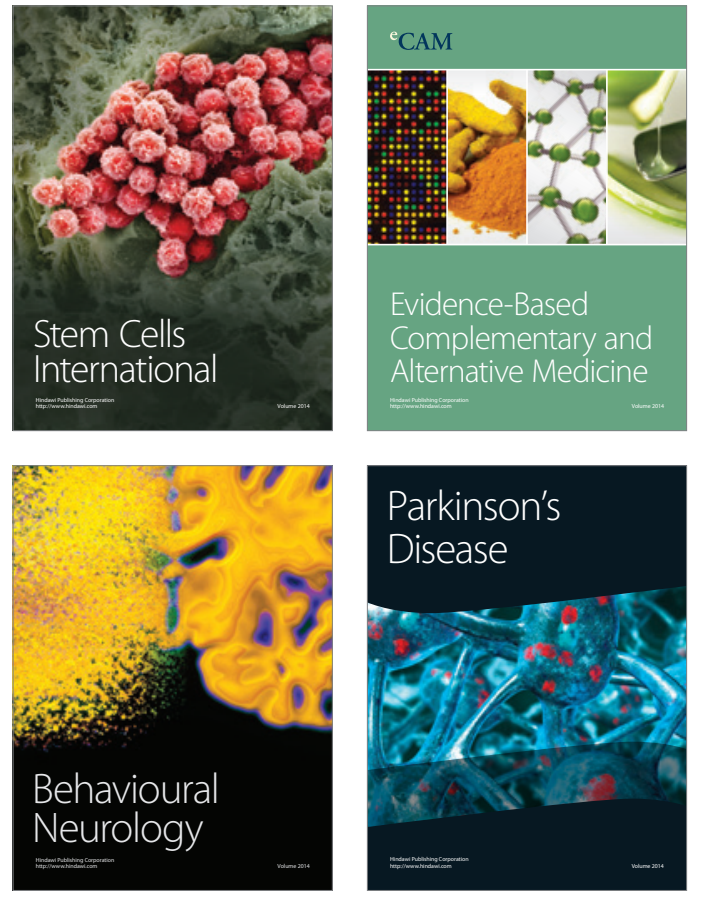
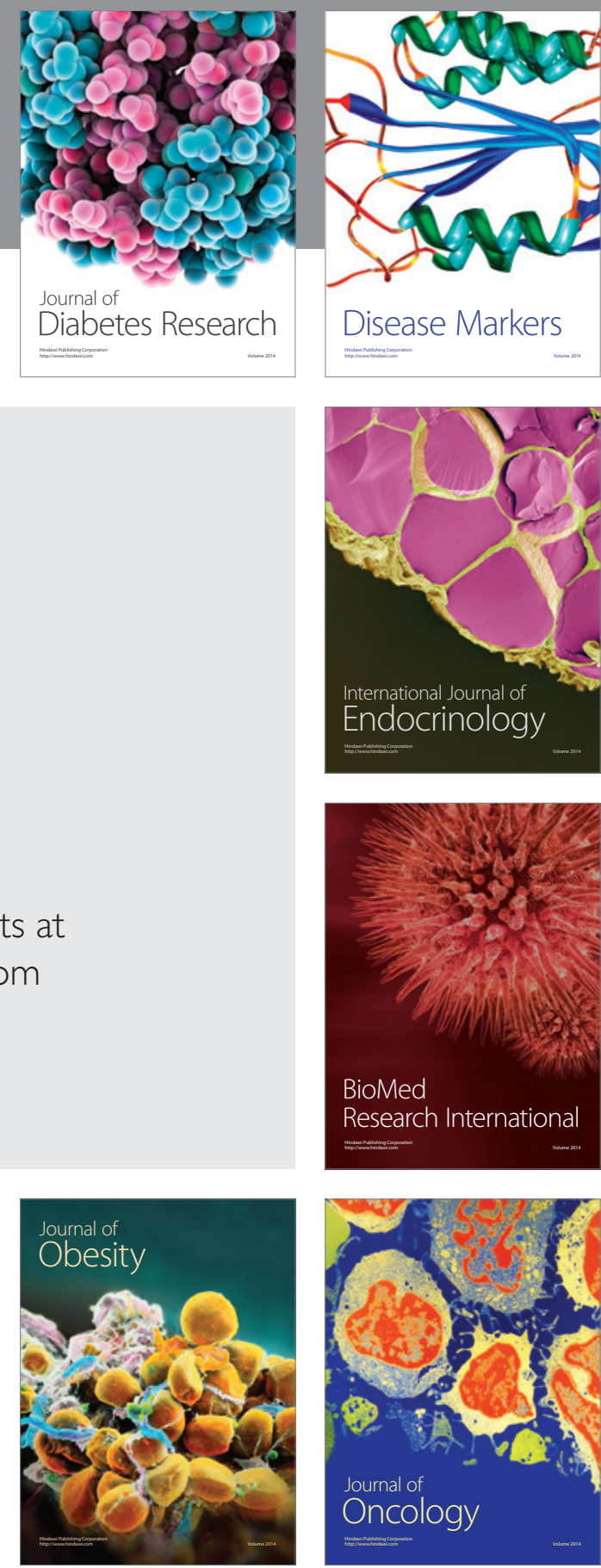

Disease Markers
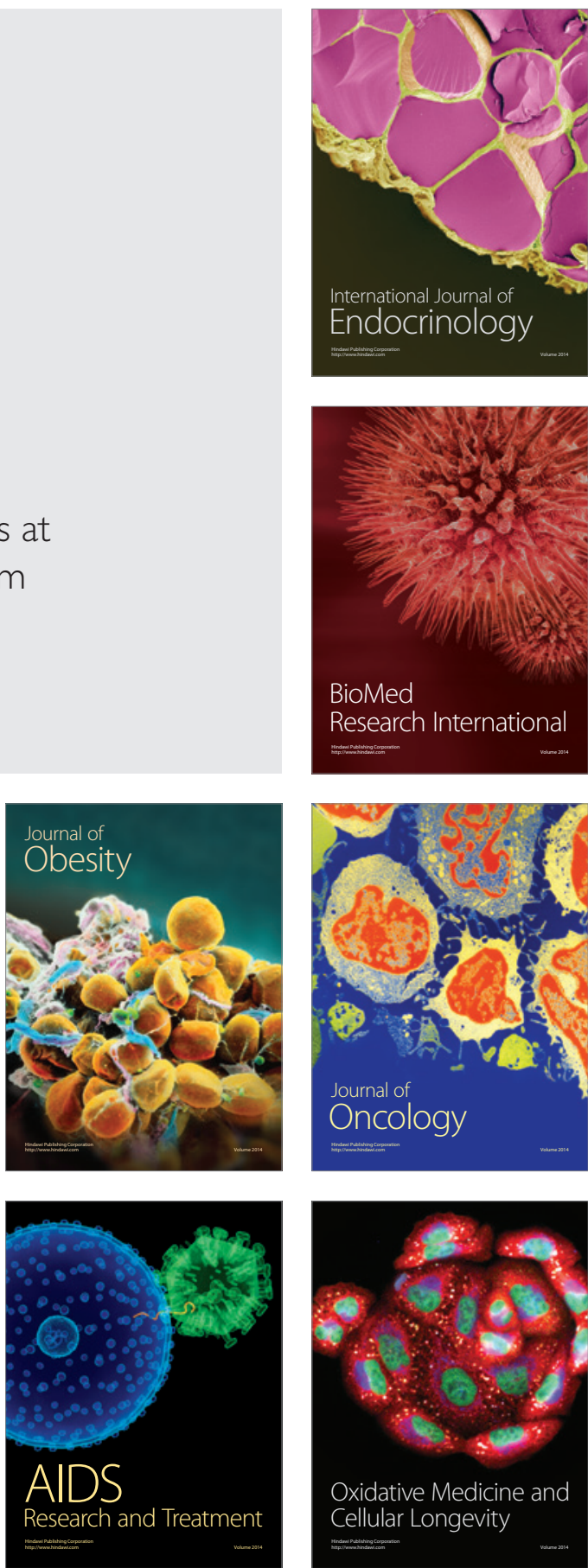